\title{
The rapid spread of early farming from the Aegean into the Balkans via the Sub-Mediterranean-Aegean Vegetation Zone
}

\author{
Raiko Krauß $^{\text {a, }}$, Elena Marinova ${ }^{\text {b, c }}$, Hanne De Brue ${ }^{\mathrm{d}}$, Bernhard Weninger ${ }^{\text {e }}$ \\ a Institute for Prehistory, Early History and Medieval Archaeology of the Eberhard Karls University Tübingen, Schloß Hohentübingen, Burgsteige 11 D-72070, \\ Germany \\ ${ }^{\mathrm{b}}$ Center for Archaeological Sciences, KU Leuven, Celestijnenlaan 200E, b.2408, B-3001 Leuven, Belgium \\ ${ }^{\mathrm{c}}$ Royal Belgian Institute for Natural Sciences, Department Quaternary Environments \& Humans, Rue Vautier 29, B-1000 Brussels, Belgium \\ ${ }^{\mathrm{d}}$ Geography Research Group, Department Earth \& Environmental Sciences, KU Leuven, Celestijnenlaan 200E - P.O. box 2409, B-3001 Leuven, Belgium \\ e Institute for Prehistory, University of Cologne, Weyertal 125, D-50931 Köln, Germany
}

\section{A R T I C L E I N F O}

\section{Article history:}

Received 26 April 2016

Accepted 16 January 2017

Available online $\mathrm{xxx}$

\begin{abstract}
A B S T R A C T
Close examination of the geographic position of Early Neolithic settlements in SE-Europe shows that the oldest sites are almost exclusively situated in some very specific biogeographic areas. These earliest Neolithic settlements are all concentrated in a region that Pavle Cikovac calls the Sub-MediterraneanAegean (SMA) biogeographic region. It covers the northern and north-western edge of the Aegean, including Thessaly, Greek Macedonia and Greek Thrace, and extends further into the Balkans, but only along the valleys of the Vardar (Axios), Struma (Strymon) and Mesta (Nestos) rivers. Surprisingly, although Thrace is the closest landscape to Anatolia, it does not contain any sites of the earliest phase of the Neolithic at all beyond the narrow zone of the northern Marmara. In the present paper we explain this remarkable situation in terms of the natural environment in this particular region of the Southern Balkans. To begin, we propose that the lack of oldest Early Neolithic settlements in Thrace is related to the extreme microclimate of this region. As shown by modern vegetation analogues, Thracian oriental hornbeam-downy oak forests are exposed to stronger continental influence with frosts in the winter and average temperatures during the coldest months that are ca. $2-3{ }^{\circ} \mathrm{C}$ lower than those in the Central Balkans that have Sub-Mediterranean vegetation. In general terms, what we may expect is that the earliest Neolithic groups would first appear in regions with similarly mild conditions, on a yearly average, to those in the Mediterranean. Such mild conditions are indeed present in the SMA biogeographic region. On the other hand, before moving further to the north along the north-south oriented river systems of the Central Balkans, the Neolithic economy based on agriculture and stockbreeding would first have to be adapted to the relatively harsh winters in the Balkans. In consequence, it would have been possible to apply the new Neolithic lifestyle in the neighbouring areas of Thrace, Walachia, Dobrudzha and the Carpathian Basin only after a certain period of adaptation. Available ${ }^{14} \mathrm{C}$-data show that the adaptation period is identical to the time-span of Rapid Climate Change (RCC: 6550-6050 calBC) as defined in previous studies.
\end{abstract}

(ㄷ) 2017 Elsevier Ltd and INQUA. All rights reserved.

\section{Introduction}

Following 6100 calBC, a complex Neolithic package of new ideas, capabilities and technologies - comprising some of the most important cultivated cereals and legumes, a characteristic set of domesticated animals, a developed settlement infra-structure, an advanced technology in grinding-stones, as well as a diverse

\footnotetext{
* Corresponding author.
}

spectrum of highly aesthetic pottery products - spread with the incredible speed of some $2000 \mathrm{~km}$ in less than 200 yrs from the Aegean through the Balkans into the southern Carpathian Basin. Although such quasi-instantaneous Neolithisation of SE-Europe is well-known to archaeologists (Guilaine, 2000/2001; Zvelebil, 2001; Clare and Weninger, 2014), it is in complete contradiction to socalled Wave-of-Advance models (Ammermann and Cavalli-Sforza, 1984), which instead propose the existence of a demographically motivated, much slower (by a factor 10 ) average speed of $\sim 1 \mathrm{~km} / \mathrm{yr}$ for the Neolithic move. By whatever mechanism, for example 
random walk or directional, and by whatever carrier, for example of ideas instead of people, this Wave-of-Advance approach to Neolithic dispersal has been recently refuted once again, this time by application of the very method on which it was supposedly founded, i.e. radiocarbon dating (Weninger et al., 2014). In terms of the historical reality of scientific rationality quite telling, the observed rapidity of Neolithisation is equally in conflict with the opposite theory, i.e. an entirely autochthonous development of the complex package by the local Mesolithic 'substrate' (cf. Srejović, 1973: 176-180). Recently, the continuing discussion (Benz, 2000; Özdoğan, 2011) has been extended to include the question whether the spread of Neolithic lifestyle from its core zones in the Levant and upper Mesopotamia to the West (Braidwood, 1952; Aurenche and Kozłowski, 1999) could have its background in climatic variability (Clare, 2010, 2016; Weninger et al., 2009).

Whatever approach we favour, the Neolithisation of SE-Europe is incomprehensible without an understanding of the developments within its many source regions. As is well-known, the area of the northern Fertile Crescent represents the main single region in which the most important cultivated cereals such as einkorn wheat, barley and emmer are known to have grown wild, and also where the predecessors of the domesticated sheep and goat were present (Watkins, 2007). In view of recent palaeogenetic studies (e.g. Scheu, 2012; Geörg, 2013; Bollongino et al., 2015; Scheu et al., 2015) even the theoretical possibility that wild forms of at least cattle and swine could have been locally domesticated in SE-Europe now seems highly improbable. Nonetheless, from the obviously to be assumed long-distance transfer of animal, plant, and human DNA (Hofmanová et al., 2016) from the Near East to SEEurope, and this means a (probably stepwise) movement of many real molecules over many thousands of kilometres, we should not immediately conclude that the underlying cultural trajectories for the dispersion of animal and plant DNA must - by necessity - have actually taken a 'long time'. Formulated differently, it is only seemingly logical to associate, but actually not at all justified to equate apriori (i.e. before having looked), a 'long' geographic distance of thousands of kilometres with the 'long' time it may take to travel from the Near East to Europe, such that any movement from one place to the other will by necessity (?) require hundreds of breeding generations. To avoid such flawed thinking, evidently still today underlying the Wave-of-Advance approach, we must be very careful in distinguishing between the temporal and the geographic scale, and this applies in particular to what we imagine are long/ short times, and what are long/short distances, in relation to what such concepts could have meant during the Neolithic. Firstly, among modern archaeologists, there is general agreement that the initial domestication of plants and animals within the Fertile Crescent is best described as a retracted process, and to which we may adequately assign millennium-scale time-ranges (see Riehl et al., 2015). However, looking closer at the ${ }^{14} \mathrm{C}$-database it becomes apparent that similarly slow ( $\sim$ millennium-scale) dispersion processes are really only obvious in cultural terms for certain components and sub-regions of the Pre-Pottery Neolithic, and even then only on broadly superficial scales, and surely not for the developments during the much later Pottery Neolithic. At the latest around 6000 calBC, and according to available data actually beginning some 500 yrs earlier, the geographic range of the Neolithic lifestyle rapidly increases, and this is perhaps most visible in the stepwise expansion of Neolithic lifestyles out of North Mesopotamia to the East ( 6000 calBC), out of the Levant into NEAfrica $(\sim 6000$ calBC), as well as in westward direction to the Aegean ( 6550 calBC), but where it not only arrives abruptly, but also leaves again abruptly ( 6000 calBC) both in northern direction towards the Pannonian Basin, as well as along the Adriatic coast, and finally (but only $\sim 200$ yrs later) to reach the Iberian Peninsula. As it appears, all these rapid and long-distance movements must have been underway, at the latest in the Neolithic mind, the very moment the climatic amelioration following the end of RCC must have become apparent even to the most convinced Neolithic anticlimate skeptic (Weninger et al., 2014). Indeed, even today is there much pride and interest in travelling both geographically and environmentally extreme distances in the shortest of time, and we may assume the same applied to prehistoric adventurers/scientists. What is more, even superficial analysis of available Neolithic ${ }^{14} \mathrm{C}$ data informs us that the transition from the Mesolithic to the Neolithic not only in the Aegean and adjacent parts of SE-Europe, but in essentially all circum-Mediterranean regions was accompanied by an abrupt transition in Economy, but equally so in the Neolithic Mind. In our view we may readily assume, even when lacking direct confirmation from empirical data (e.g. historical sources), that the Neolithic expansion would be accompanied by some entirely new concepts in thinking, in particular in terms of the semantics of what makes short and long geographic distances. Similarly, we may assume corresponding changes in the assumed size of the world, both in metric terms and all the more in mental categories. For all we presently know the begin of this specific mental transition dates to the very begin of the RCC-period (65506050 calBC). Similar changes in societal and mental landscapes, but for the much earlier transition from hunter gathering to farming lifestyles, were noted by Bar-Yosef (2011) as being due to the impact of the Younger Dryas.

\subsection{Maritime networks and land routes in the Aegean and SE- Europe}

The Neolithic dispersal from the Near East into the Aegean can be attributed to the existence of long-distance coastal networks that are known to have been operating throughout the entire eastern Mediterranean already during the preceding Epipalaeolithic/Mesolithic and/or Pre-Pottery periods (Reingruber, 2011; Maviátๆs, 2014; Horejs et al., 2015). The same applies to the successful transfer of taurine cattle from the Levant to Cyprus across the open sea, which is documented already at the very onset of the Holocene (e.g. Zeder, 2008), as well as to the wide distribution of Melian obsidian in the Aegean during the Mesolithic (e.g. Bergner et al., 2009; Reingruber, 2011; Milić, 2014). It would appear natural that from some time onwards these pre-established marine networks would be used to transfer other components of the Neolithic package, including its sedentary lifestyle, grinding-stone technology, farming and animal husbandry, as well as the transmission of pottery products. Let us not dwell on the altogether secondary question, as goes for the material artefacts, whether it were the products themselves or rather their modes of production that had to be transferred. If we instead undertake a comparison between the different fields, it is in our view the adaptation to the continental conditions in SE-Europe with its markedly cold winter months that must have represented the greatest challenge to the newcomers.

This already follows from an examination of the different landscapes (terrestrial, coastal, marine) that the newcomers encountered along the routes from the Near East. What we call here the natural route, is to move (or sail) along the southern coast of Turkey, then turn into the Aegean, and finally decide which of the many islands, coastal floodplains and mountainous regions is the most preferable. The existence of this southern (coastal) route is confirmed, albeit only indirectly, by the location of the two major settlements on Turkish West Coast, that is Çukuriçi and Ulucak, both of which represent the Neolithic in its very earliest stage, and each of which has essentially the same foundation date of $6550 \pm 30$ calBC (Weninger et al., 2014). It is the same date as 
established for the earliest documented use of the Franchti Cave on the Peloponnese (Weninger et al., 2014).

In parallel to this southern (coastal) route, one would at first anticipate that the Neolithic might also have spread simultaneously out of NW-Anatolia, utilizing the entirely unproblematic crossing both of the Dardanelles and of the Bosporus, first into neighbouring Thrace and northern Greece, and from there further into the Balkans. Yet, precisely the Thracian Plain is one of the areas on the Balkan Peninsula, in which Early Neolithic settlement has been shown to have taken place particularly late (Nikolov, 1990; Todorova, 1990). It is noteworthy that archaeological research in Thrace not only began very early, but always had special focus on the Neolithic period. Within Bulgaria, Thrace can be considered as one of the best explored landscapes. In the area of the Marmara Sea, which represents a borderland between Anatolia and SE-Europe, a marked Neolithic had already developed several centuries before the spread of agriculture and livestock-raising to Europe (Özdoğan, 2014). In contrast in Thrace, there are no known Early Neolithic finds at all that would date earlier than Karanovo I. But further to the west, the earliest Neolithic cultures north of the Aegean are definitely well-documented in the river valleys of the Vardar (Axios), Struma (Strymon) und Mesta (Nestos). In view of the much closer proximity of Thrace to NW-Anatolia this situation is puzzling and requires further explanation.

In general terms, a comparison of the Balkan Neolithic with West Anatolia reveals a distinct cultural gradient. Whereas in West Anatolia solid clay houses were built with stone foundations, those of the Balkan Neolithic are constructed more simply. Similarly, the material culture in the Balkan sphere seems quite reduced in comparison to that in West Anatolia: the pottery in the latter region is clearly of greater quality and multifaceted. Despite these differences, an understanding of the pottery development in West Anatolia enables us to recognise the moment at which the basic impulse of Neolithisation also commenced in SE-Europe. There are altogether three innovative elements in pottery production that are characteristic for the oldest pottery of the Balkans, and all three elements are recognisable at the West Turkish sites of Ulucak, here for the first time in Ulucak Va, as well as at Çukuriçi Höyük, for the first time in Period VIII. The three pottery elements are, firstly, Impresso decoration; secondly, depictions of ungulates applied in relief on the vessel's surface; and thirdly, white-on-red painted pottery. Although white painting on pottery is likely to be somewhat older in West Anatolia than in SE-Europe, once introduced it appeared more frequently. Also older on the Turkish West Coast is the tradition of the red slip on pottery, but this is an omnipresent element which also emerges with the Neolithisation of the Balkans.

One crucial difference, however, is the distinct bonding of the West Anatolian Neolithic with the Mediterranean Sea, in contrast to the Neolithic spread into the Balkan-Carpathian sphere, which must have progressed over land. On the land routes it would appear natural for the rivers to play an important role, and boats were surely important for navigation on long stretches of rivers. Yet, the bond with a river valley is not comparable to maritime contact over the open sea. Indeed, the very connection of agriculture and animal husbandry with sea travel over long distances would appear paradoxical: at first view, the Neolithic form of economy requires a sedentary way of life, whereas sailing rather implies the mobility of human communities. Whether or not there existed groups with different forms of livelihood, including communication specialists who may have interacted solely for economic reasons, cannot be determined at the present state of research. Whatever the case, the very specific natural environment of West Anatolia with its offshore Aegean islands offers optimal preconditions for a complex exchange system based upon maritime travel, as described by Bronisław Malinowski with reference to inhabitants of the Trobriand
Islands (Malinowski, 1922 [1979]). With the choice of title for his book, Malinowski refers intentionally to the myth of the Argonauts, which is set on the Aegean-Pontic coast. During the Neolithic, archaeologically tangible material goods from the Aegean such as obsidian and also Spondylus shells could have served as exchange goods, as was the case in Melanesia at the beginning of the 20th century. Moreover, although archaeologically intangible, along with the trading goods there would be transfer of the manifold immaterial social, economic, and religious aspects that are of importance for all exchange systems (Malinowski, 1922 [1979]: 115-141), and which we may assume are also conditional for prehistoric societies. Such aspects can be recognised, in particular, in the close analogies between ceramic styles during the SE-European and Anatolian Neolithic, and which can be interpreted as more than just a reflection of personal contacts or preferences. In geographic terms, we can be sure that the Cyclades, the Troad, the islands of the Sporades and the Turkish and Greek littorals of Thrace would all have participated in maritime exchange networks during the Neolithic period in Northwest Anatolia and the Aegean (Horejs et al., 2015).

\section{Two different developments in the Marmara region}

According to a model recently presented by Mehmet Özdogan, during the Early Neolithic the cultural development in the Marmara region can be divided into two clearly distinguishable spheres (Fig. 1): a western sector along the coastal strip of the Aegean, and an eastern sector with sites concentrated almost exclusively within the present-day limits of the mega-city of Istanbul and its surroundings, as far south as Lake Ulubat (Özdoğan, 2014: 41-47). Although in both regions the Neolithic can be deduced from common origins in southwestern Anatolia, they nonetheless developed slightly different "Neolithic packages", which are expressed by "different technologies" and "distinct identities" (Özdoğan, 2014: 41-43). Technological differences are manifest in the bullet-core technique and the use of obsidian as raw material for stonechipping in the East, and the so-called Karanovo-blade technique in the West. Distinct identities are expressed by the presence of extra-mural burials in the East, which are however completely missing in the West. Characteristic for the Western Marmara are certain aspects of ceramic decoration such as red-slipped surfaces and mat-impressed bases (Özdoğan, 2014: Fig. 12). What is common to both regions is the occurrence of anthropomorphic clay figurines, although they are rare in the East.

According to Özdogan (2014: 2f.) the most obvious reason for the observed cultural variability in the two regions would be major differences in the underlying formation processes already during the Early Neolithic. Whereas the Neolithisation in the Eastern Marmara could be seen as terminate moving of a Neolithic population into an already inhabited area, which would require merging of the incoming farmers with local groups of hunter gatherers, the Neolithisation process in the western Marmara could rather be seen as a movement of farmers in successive waves into areas void of any previous population. Note that, in both regions, the respective judgement is based on intense and systematic surveying. For the Western Marmara there is a complete lack of any data that might indicate the existence of a pre-Neolithic population.

A view of the Marmara region as seen from the Aegean reveals further west-east differences. The settlement of Aktopraklık B, for instance, displays a semi-circular, closely built plan of rammed clay houses with interior posts supporting the roof (Karul and Avcl, 2013: Figs. 12-15, 17). Such constructions are also documented in Otzaki-Magoula, in Sesklo and Achilleion, in Thessaly (Milojčić, 1983: Figs. 2-3; Alram-Stern, 1996: Fig. 29; Theocharis, 1973: Fig. 179, Gimbutas et al., 1989: 32-68). Documented further east 


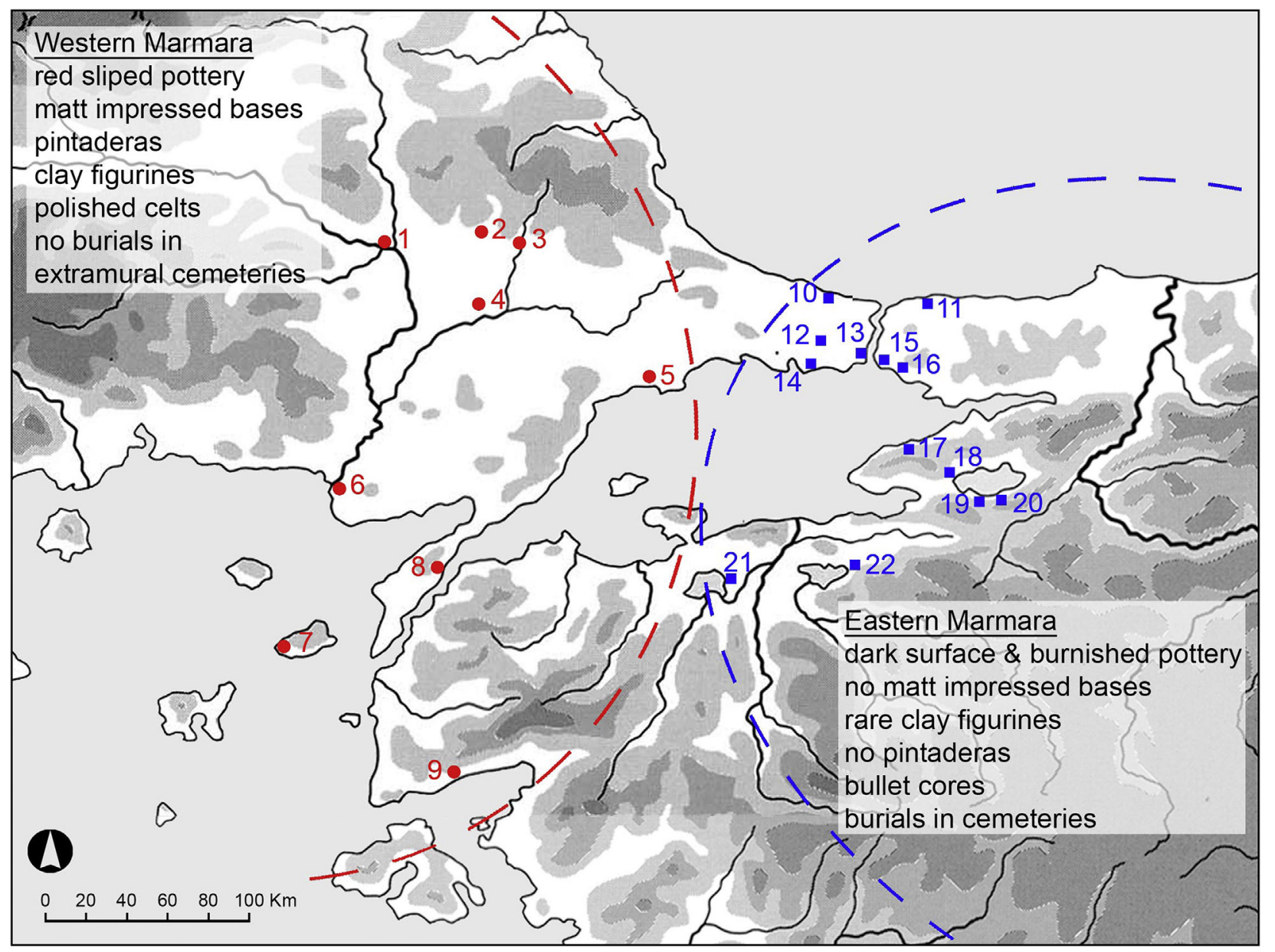

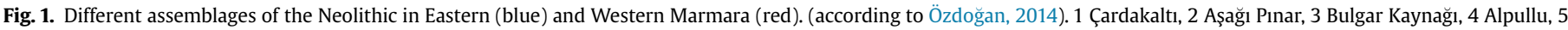

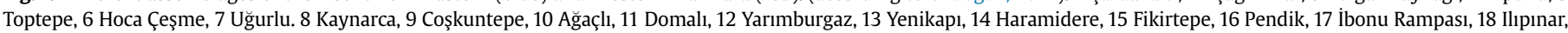

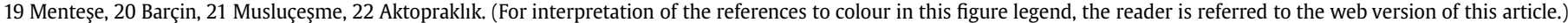

are framework clay buildings (wattle and daub), for example, in Barcin Höyük (Gerritsen et al., 2013: 6-7, 9) and in Menteșe (Roodenberg and Alpaslan-Roodenberg, 2013: Fig. 9). Initially, Ilıpınar also has wattle-and-daub structures (Roodenberg and Alpaslan-Roodenberg, 2013: Fig. 3). Then, as of layer VI, the characteristic architecture of row houses arranged in a semi-circle and built of air-dried mud bricks was adopted (Roodenberg and Alpaslan-Roodenberg, 2013: Figs. 4-7). As it appears, the Marmara region became integrated in the Aegean Neolithic in a stepby-step manner. Peculiar to the east of this region is the burial of deceased in cemeteries. This practice is not attested anywhere else in the entire Mediterranean area at this early time.

\section{The circumvention of Thrace}

Viewed in a wider perspective, it appears that the Neolithic of the Eastern Marmara is not just loosely connected to the earliest Neolithic in the Balkans. The Eastern Marmara represents almost a barrier between the development of the Neolithic in Anatolia and the Balkans. It is not that relationships did not exist between Anatolia and the Balkans; instead, whenever contacts were established, these contacts always took place while bypassing the Marmara region. What is also conspicuous, even though the number of known Early Neolithic sites has increased significantly, the general picture of the spread of Early Neolithic settlement into the Balkans is still as described by Vassil Nikolov already in 1990 (Nikolov,
1990). This is as follows. Densely settled areas are always located in river valleys flowing into the Aegean as well as in the Central Balkans, but with almost no sites located in the areas east and west of such concentrations. Still today, the Struma valley appears to represent the major route for the Neolithisation of the Balkan region. Indeed, starting from the Aegean, the Struma and Vardar river valleys seem to be the only two corridors of any importance for the spread of the Neolithic to the North. Given this communication system, one might expect that the further any given site is located away from the Aegean, the less it would compare with sites in West Anatolia and in Greece. Yet, the exact opposite applies.

The unexpectedly strong relations that exist between Anatolia and the Early Balkan Neolithic over large distances are perhaps best illustrated by the following two known examples. First, there is no difficulty at all in linking the pottery inventory of Kovačevo in the Struma river valley with the material from Hacilar in the southwest Anatolian lake district (Lichardus-Itten et al., 2006: 86-88; Brami and Heyd, 2011: 182f.). Second, excavations at Dzhuljunica in northern Bulgaria have yielded pottery that can also be found at several Early Chalcolithic (in Turkish terminology: after 6000 BCE) sites in central West Anatolia, including Ulucak, Ege Gübre and Çukuriçi (Krauß et al., 2014: 58f.). In both cases, the pottery similarities are quite plausibly linked to the river systems of the Central Balkans. What is even more conspicuous, however, is that for Dzhuljunica there does not exist any direct connection via NWAnatolia. For this route, which would indeed have been the 
shortest (via the Black Sea coast), the Eastern Marmara acts as a complete barrier for interactions of any kind. Furthermore, already a brief glance at the distribution map of the so-called earstuds (labrets or bucrania idols: a find category clearly restricted to the oldest phases of the Early Balkan Neolithic), illustrates the bypassing of the whole Marmara region (Fig. 2). Since there are not many finds of this specific category in West Anatolia, it is actually questionable whether these artefacts originated from areas east of the Aegean, as one might assume. Whatever we infer for these idols, the general picture is that on their way into the Balkans the earliest farmers not only bypassed the Marmara region but also circumvented Thrace. As mentioned above, this is all the more astonishing, given that inner Thrace is the landscape situated closest to Anatolia, and since there are no sites of the earliest phase of the Neolithic there at all.

To explain this specific find situation we could now argue that major sedimentation rates in the wide alluvial plain of the Marica (Meriç/Evros) and Tundzha Rivers have deeply buried the sites, assuming that they do actually exist but remain covered from view, or that a significant rise in Black Sea level would have flooded the former coastlines. Indeed, little is known about the palaeogeographic development of the Thracian Plain, although landscape and soils in SE-Europe and in particular in Northern Greece have undergone significant changes since the Neolithisation (Ghilardi et al., 2008; Lespez et al., 2000; Lespez et al., 2013; Krahtopoulou and Veropoulidou, in press). Nevertheless, taking the conspicuous lack of earliest Neolithic sites in Thrace as a present fact, in the following we put forward and evaluate the hypothesis according to which the spread of earliest Neolithic settlement into the Balkans can be linked to and is partly explained by the existence of some specific bioclimatic and environmental (vegetation) zones.

\subsection{Neolithisation along the SMA Vegetation Zone}

A look at the situation of the Early Neolithic find spots in SEEurope reveals that the oldest sites are almost exclusively spread

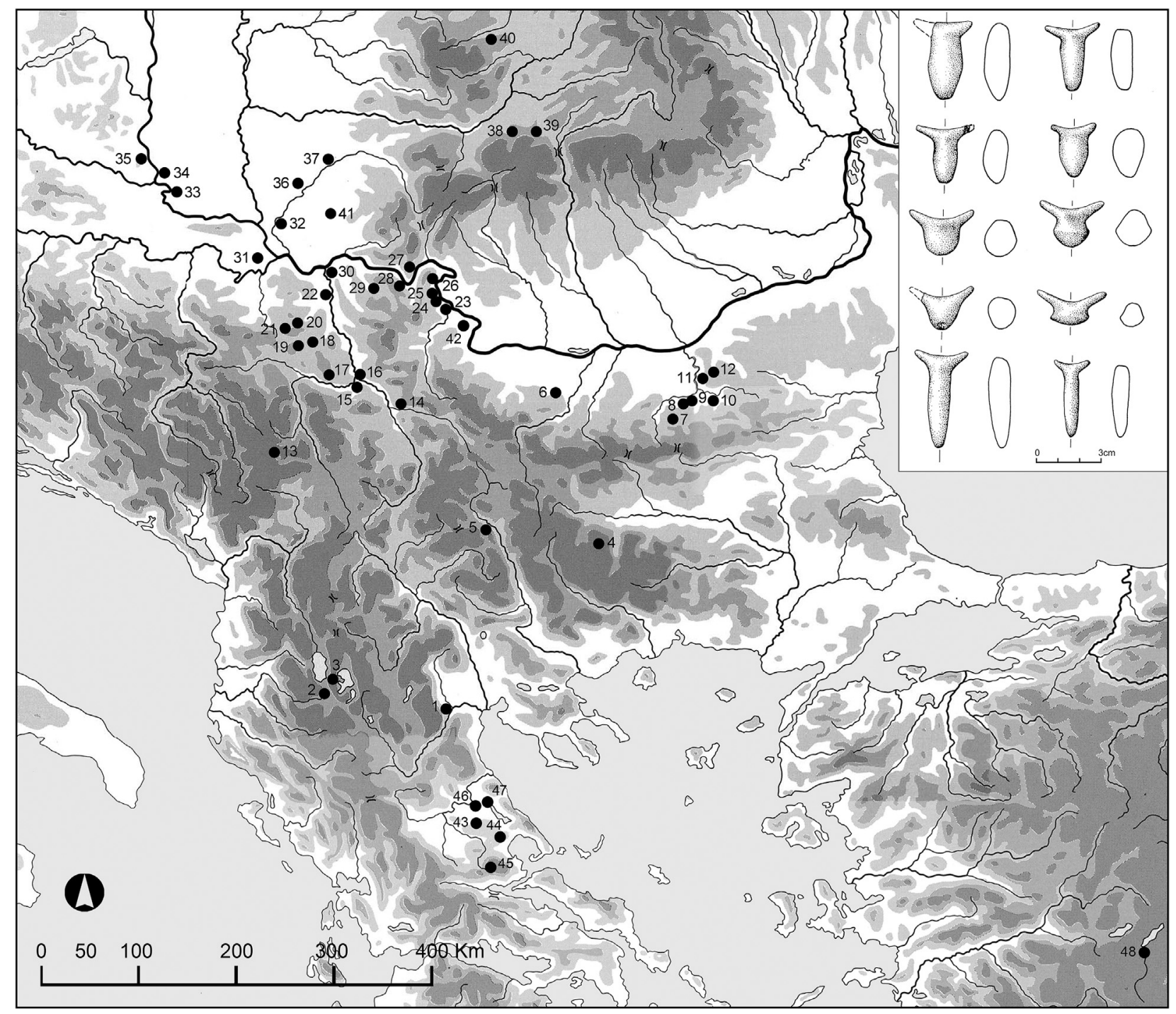

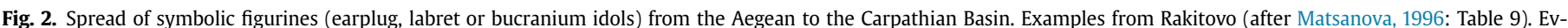

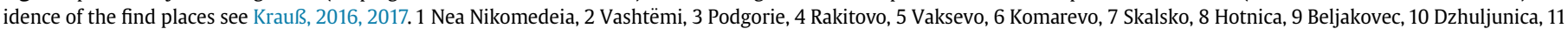

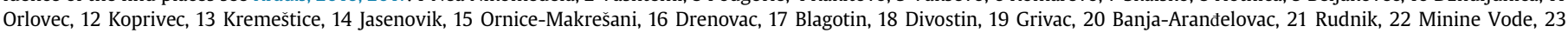

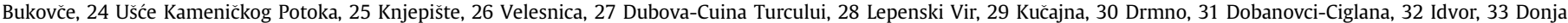

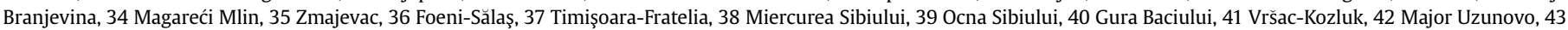
Zappeio, 44 Sesklo, 45 Achilleion, 46 Argissa Magoula, 47 Soufli Magoula, 48 Hacilar. 
over a specific biogeographic area (Fig. 3). The earliest Neolithic settlements are concentrated in a region that has been described by Pavle Cikovac as the Sub-Mediterranean-Aegean (SMA) biogeographic region (Cikovac, 2002: 22-25). This particular region includes the northern and north-western edge of the Aegean, including Thessaly, Greek Macedonia and Greek Thrace, and extends further into the Balkans only along the rivers Vardar, Struma and Mesta. The region further encompasses the actual Vardar zone, as well as northern Pelagonia in the Republic of Macedonia (F.Y.R.O.M.). In Bulgaria it is limited to the narrow river banks of the Struma and Mesta rivers, which open towards the south to the northern Aegean in a canyon-like landscape. The high mountain barriers in the southern Balkans, some reaching more than $2000 \mathrm{~m}$, were an obstacle to the further spread inland of the influence of the Mediterranean climate (cp. Cikovac, 2002: 25). Correspondingly, sub-tropical flora is found only in the Thessalian basin, in the broad coastal zones of Macedonia, and in the three aforementioned river valleys. Among the flora to name here are foremost thermophile species such as the semi-evergreen Macedonian oak (Quercus trojana), the hop hornbeam (Ostrya carpinifolia), the Oriental hornbeam (Carpinus orientalis) and the manna ash (Fraxinus ornus) (Cikovac, 2002: 25).

The SMA biogeographic region is further defined as the area of the natural spread of the European olive tree (Olea europaea)

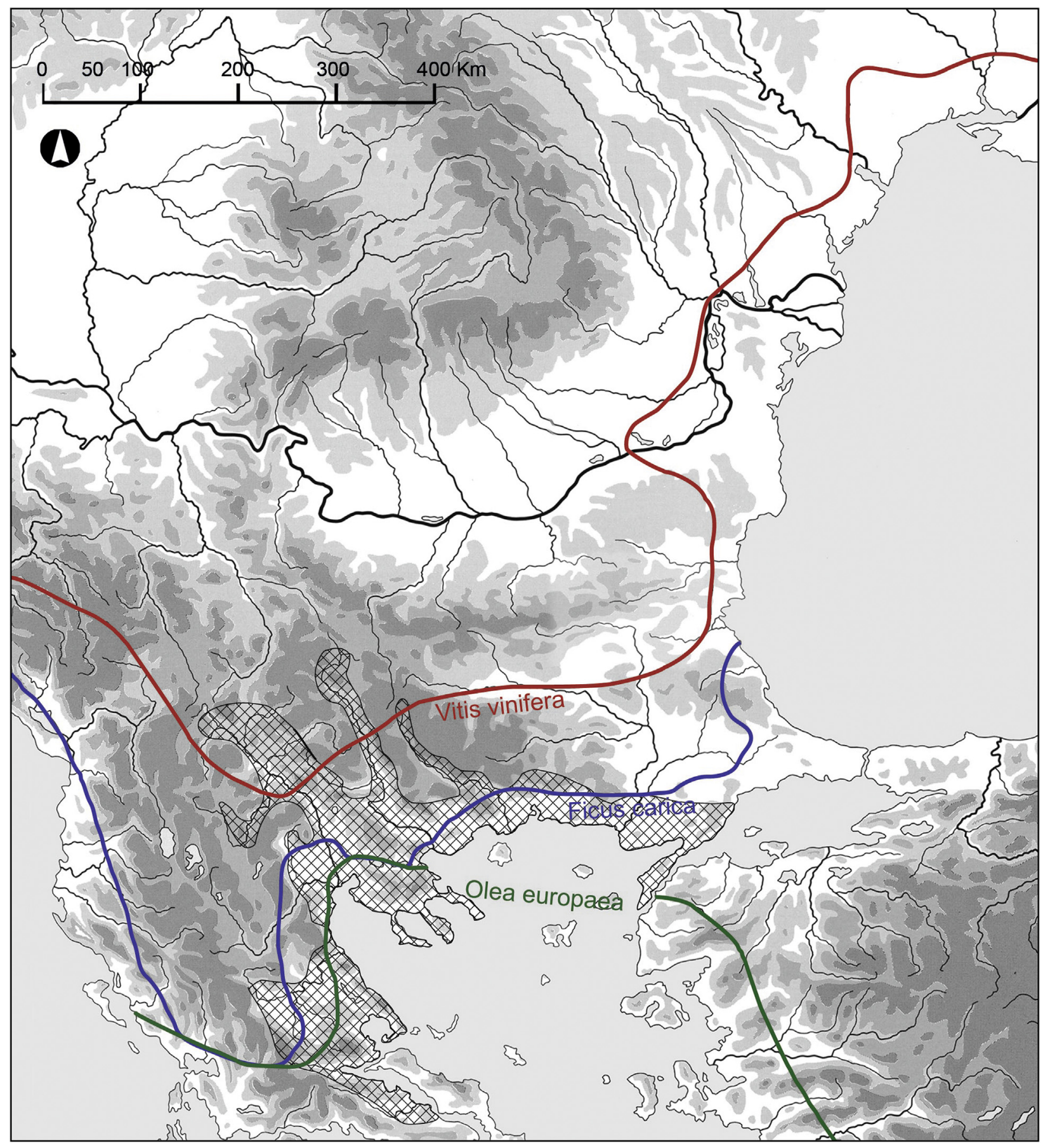

Fig. 3. Northern border of the natural spread of olive tree, fig tree and wild grape. Hatched is the SMA biogeographic region (after Cikovac, 2002: 22-25). 
(Zohary et al., 2012: map 15), which in a remarkable way covers those areas that are part of the maritime networks of the circumAegean Neolithic described above. Of course, the olive tree was cultivated at a significantly later time. However, we are concerned here specifically about those areas that have optimal conditions for agriculture, and for which we propose the theory that these areas overlap with the distribution area of the typical Mediterranean crop plants. The distribution area of the wild olive tree extends along the narrow coastal zone of western Anatolia, in Macedonia only on the Chalkidiki peninsula, in the eastern part of Thessaly, and further to the Greek mainland south of the Pindos Mountains, and finally of course the Aegean islands. The distribution area of the wild fig tree (Ficus carica) extends only a little further to the North (Zohary et al., 2012: map 17). It encompasses the southern edge of Turkish Thrace, the broad coastal zone of the northern Aegean as far as the Rhodope Mountains, and in principle the entire Greek mainland, with the exception of the Pindos. This given, the original distribution area of the olive and fig tree apparently circumscribes the area which was ideal for an agricultural way of life in the early Neolithic period. Correspondingly, although based on a still limited number of radiocarbon dates one can conclude that the areas of the Greek mainland within the distribution area of the olive and fig tree had already become Neolithic in the 65th century calBC (Reingruber, 2008: 613-616; Maviátms, 2014), most probably initiated from West Anatolia.

The natural distribution of the wild grape (Vitis vinifera), whose cultivation is known to have begun at some time in the 4th millennium calBC (Zohary et al., 2012) and which belongs to one of the most important cultivated plants in the region, can also be considered a geographically delimiting factor for the Aegean Neolithic. Although its cultivation did not begin in the Early Neolithic, our theory according to which the oldest Early Neolithic in the Balkans emerged from zones with ecological conditions similar to the Aegean, can possibly be traced by studying the distribution of this wild form of grape. In addition to the Mediterranean sphere in a broader sense, the original distribution area of the wild grape also encompasses the entire littoral of the Black Sea (Zohary et al., 2012: map 16). In SE-Europe the line of its northernmost distribution follows the coast of the Black Sea, runs somewhat centrally through the Thracian Plain towards the West and then follows the north-eastern ridge of the Dinarids as far as the rim of the Slovenian Alps. The distribution of wild wine thus embraces the Dobrudzha, Eastern Thrace and the Rhodopes, all of Macedonia as far as the northern Vardar zone, Albania, Montenegro, western Bosnia and Dalmatia. In contrast to the narrow distribution area of the olive tree, for wild wine only a sporadic congruency with the distribution of the oldest Early Neolithic period can be discerned. In the following we address the question as to the underlying cause of this curious situation.

To begin, let us take a step back and have a closer look at the Neolithic economy in its initial period: as is well-known, the Neolithic was developed some 10.000 yrs ago in the Fertile Crescent, and expanded as far as the Aegean Sea only much later, in the course of the 7th millennium calBC. In principle, however, the Neolithic economy was a form of husbandry that could be conducted in many different geographic regions. All that is necessary is a landscape suitable for the cultivation of steppe grasses, and for pasturing ungulates. Open landscapes were initially preferred for settling, where crop cultivation and pasturage were possible without any laborious clearing of trees. The main challenge for the earliest farmers was to protect the sowings, and it is precisely this aspect that is most likely to have led to the sedentary lifestyle that is so characteristic for early farming. A moderately warm climate and sufficient precipitation would have been favourable for the growth and ripening of the early kinds of cereals. The longer duration of continental winter with week-long periods of frost would have presented a serious hindrance to crops. Thus, in combination, it can be assumed that the earliest agriculture would have been initially restricted to areas with correspondingly optimal climatic conditions for growing and harvesting cereals. Hence, leaving the Mediterranean zone in a northern direction would have meant being confronted with shorter growing seasons and later frosts, which would have been a real threat for a subsistence based on annual crop cultivation. This would readily explain why the earliest Neolithic in the Balkans is only to be found in areas that are located within the range of the SMA vegetation zone, where they are not threatened by harsh winters.

Regions with a marked continental winter climate are also likely to have had an unfavourable effect on animal husbandry, although not an existential threat. In the course of a typical year, from late spring until autumn, pastures in the high mountains of the southern Balkans offered an ideal pasturage. However, this situation is seriously threatened by cold winters. For this very reason, a seasonal transhumance has been long practiced in this region, even until historical times, which entails protecting the grazing animals during the winter in shelters that are located either in the mountain valleys, or else in the milder coastal zones of the Mediterranean (Beuermann, 1967). Hence, when proceeding from existing maritime networks of the Aegean, it is the SMA biogeographic region that would have been best suited for the Neolithic manner of economy. The further expansion would then have naturally followed the SMA zone in northern direction, along the valleys of the Vardar, Struma und Mesta rivers. In order to live in regions on the other side of the mountain barriers of the southern Balkans, based solely on Neolithic economic activities, meant that the Neolithic package had to be adapted to conditions of the comparably harsher and longer winters.

\subsection{The Early Neolithic in the Struma (Strymon) river valley}

The fact that the Struma valley represents one of the main routes involved in the Neolithisation of the Balkans was realised comparably late in research, and this is particularly due the lack of sites along the north Aegean coastline (Andreou et al., 2001; UremKotsou et al., 2014: Fig. 1). In many cases even today the understanding of the dissemination of the Neolithic via the Struma valley is still largely based only on the comparison of ceramic types and their decoration (Brami and Heyd, 2011; Krauß, 2011). This view is clearly augmented by the distribution of Neolithic clay stamps, which also indicate the importance of connections reaching from Pisidia in south-west Anatolia to Thessaly, and which include the great river systems Struma and Vardar that exit from the Central Balkans into the northern Aegean (Lichter, 2011: Fig. 1). Interestingly, this picture of the distribution of Neolithic clay stamps is missing in the Eastern Marmara, an absence that in turn speaks for the barrier function of that region.

Of particular interest then is the question as to the extent of any structural mutuality that might have existed between the Struma valley and southern regions, aside from the ceramic technology employed. Discussion of this issue, however, is hindered by the general lack of Early Neolithic finds in the north Aegean coastal zone, a lacuna that is most probably associated with shifts in the coastline and heavy sedimentation (Lespez et al., 2013). Diagnostic architectural contexts from the earliest Neolithic in the Struma valley are presently only known from Kovačevo. Even at Kovačevo, the Early Neolithic settlement context has been severely damaged through erosion, and also as a result of earthquakes and later intrusions (Lichardus-Itten et al., 2002: 107f.). The remaining, freestanding houses display a square ground plan with walls measuring 5-6 $\mathrm{m}$ in length and floors made of stamped mud. The 
standing walls are constructed of posts-and-framework covered by a layer of mud/daub (Lichardus-Itten et al., 2002: 108-114; Figs. 5 and $2 ; 6,1-2$ ). This kind of house construction can be traced back to structures in central West Anatolia, although the characteristic stone foundations are completely absent in houses in the Struma valley. This particular absence can hardly be explained by the lack of accessible materials; indeed, there is a plenitude of stones in the area. A post construction with several rooms is known from Bălgarčevo II; it displays features of an independent Balkan type of house, which at least cannot be traced back to the South (Pernicheva-Perets et al., 2011: 71-82).

The discovery of skeletal remains of children within the settlement of Kovačevo (Lichardus-Itten et al., 2002: 116; pl. 9,1-2; 10,1) together with the absence of cemeteries outside of the settlements are indicative of a burial custom that is possibly similar to that practiced in central West Anatolia. What we can at least say is that burial customs at Kovačevo differ distinctly from the rituals found in the Eastern Marmara, where several cemeteries are known.

The spectrum of slaughter remains in pits in Kovačevo reflects an inventory containing large amounts of domestic animals and only a small proportion of wild game, which is common for the Early Neolithic. The majority of domestic animal remains comprises sheep/goat, amounting to $65 \%$, followed by ca. $21 \%$ domestic pig. Significantly, the scholars studying the animal bones have identified good comparisons of this inventory not only with neighbouring sites in the Balkans, but also with the material found in the settlements of Nea Nikomedia and Achilleion in Greek Macedonia and Thessaly (Lichardus-Itten et al., 2002: 126; cf. Halstead and Isaakidou, 2013; see also their contribution to this volume). Finds of Glycimeris and Spondylus support a clear association with the Aegean; they appear already in the Early Neolithic layers in Kovačevo and served as raw material for making ornaments (LichardusItten et al., 2002: 127f.). Analyses of the many botanical remains found at Kovačevo show the normal spectrum of Early Neolithic cereals, including einkorn wheat, emmer, barley and hard wheat (Lichardus-Itten et al., 2002: 127). These results speak neither in favour of nor against a connection of Kovačevo with any old Neolithic region in the south, however, the weed assemblages from the site indicate clearly affiliation to the Eastern Mediterranean (Marinova, 2006: 56-62).

When studying the natural environment of the Struma valley, it becomes clear that the spread of the Neolithic into the Balkan area occurred not simply by a switch from maritime to terrestrial communication, but that ship navigation in general was no longer the preferred manner of transportation. Marine communication is typically quite rapid. However, even on land, the speed of the movement is apparently so high ( $2000 \mathrm{~km}$ in less than $200 \mathrm{yrs})$ that it is impossible to temporally and geographically resolve these pathways, even with high-resolution ${ }^{14} \mathrm{C}$-site chronology, by any kind of random-directional demographic wave-modelling (Weninger et al., 2014). From a purely archaeological standpoint, Neolithisation from the northern coastal zone of the Aegean as far as the Danube River has the appearance of representing an entirely sudden and abrupt process, that lacks any large temporal depth, and that took place during the course of the 62nd century calBC. With respect to the probable existence of different communication paths for various components of the Neolithic package, Amelie Scheu's palaeogenetic examination of domestic cattle interestingly revealed a genetic similarity between cattle in Kovačevo and Neolithic cattle in their (far away) source areas in Iran, that was ca. twice as high as between Kovačevo and Koprivec, although both sites are situated relatively close to each other (Scheu, 2012: 106). Local aurochs did not play a role in the genetic characteristics of Neolithic cattle; indeed, apparently Neolithic cattle were imported directly from the Southeast (Bollongino et al., 2008). A further implication of the genetic data is that the movement of herds of cattle in the Balkans, even on local scales, is likely associated with groups of people immigrating from widely differing regions. Namely, the spread of the Neolithic occurred far too rapidly, and the number of accompanying cattle was far too large, implying that these movements can be explained solely by assuming the existence of some loose networks of people with different economic bases. Even if pre-Neolithic populations did exist in this area, and on demographic scales for which we have absolutely no evidence, they had no attestable agency in mediating the Neolithic cultural elements. Our conclusion, based on archaeological, ${ }^{14} \mathrm{C}$-radiometric and on cattle-genetic data, is that the agents of the Neolithisation of the Struma valley must have been groups of people who were already fully familiar with Neolithic economy, who were long experienced with plant cultivation, and who were accompanied by their herds of animals.

\subsection{Neolithisation of the Vardar (Axios) river area}

The few buildings that have been discovered in the Vardar zone display a remarkably solid construction. The settlement plan of Tumba Mađari shows rectangular structures measuring up to $80 \mathrm{~m}^{2}$ in floor area (Kanzurova and Zdravkovski, 2011: 140f.). Inside the houses containers of round or square plan were firmly installed (Kanzurova and Zdravkovski, 2011: Fig. 11; 13), which until now have singular appearance in the oldest Early Neolithic in the Balkans. Such installations are best traced to the south and, thus, provide hints of contacts between the Vardar zone and the Aegean, at least with the immediately bordering area of Greek Macedonia. Prototypes could have been settlements such as Nea Nikomedia and Servia (Perlès, 2001: Fig. 9.1; Alram-Stern, 1996: Fig. 38). It is also noteworthy that the structures in Tumba Mađari do not compare well with contemporary buildings in Thessaly at all, since the latter houses were commonly constructed with mud bricks and in some cases have wall pillars in the interior to support the roof. Hence, for Thessaly, it seems that closest connections existed not on any land route, but across the Sea, directly with central West Anatolia. This also becomes apparent when we take a closer look at the building plan in Anza II, where one house is documented in the settlement as having wooden post-and-framework walls that are erected upon a stone foundation (Gimbutas, 1976: pl. 3); this building strongly resembles the solidly built structures in central West Anatolia. In the case of Anza II, since it is one of the oldest known house contexts, this manner of construction can hardly be traced back to a local origin. Nevertheless, on the upper reaches of the Vardar River some elements otherwise typical for the maritime networks of the Aegean are not present; it would appear as if they 'did not arrive'. For example, almost no obsidian tools are attested there (cp. Gimbutas, 1976: 257-282, cf. also Milić, 2014). The presence of the kinds of cereals and legumes common to the entire Aegean and Balkan zone is not surprising, nor is the clear dominance among domesticated animals of sheep/goat over cattle and swine (Gimbutas, 1976: 300-331). Close contacts with the maritime networks in the Aegean are again attested by artefacts made of Spondylus, which appear in comparably large numbers already in the oldest settlement layers in Anza (Gimbutas, 1976: 242-251; cf. also Bajnóczi et al., 2013).

Turning now to the manner in which such partially local contacts are expressed in terms of pottery styles, it is important to recognise that a widely similar spectrum of forms developed throughout the entire zone of the Southern Balkans, at least during the advanced Early Neolithic. This spectrum extends indeed all the way from the Western Balkans to the Black Sea, and points to some quite intensive contacts at long distances, during the first half of the 6th millennium calBC. Nonetheless, these contacts only formed 
after the actual phase of Neolithisation, and are founded upon landbound communication between individual groups of people. Considering the rugged topographic texture that is geographically sectioned by some extremely high mountains, foremost the Southern Balkans between the Albanides, Baba Mountains, Voras (Kajmakčalan), Belasica, Rila, Pirin, the Rhodopes and the Balkan Mountains themselves, the intensity of such contacts is indeed astonishing. Ultimately, a greater mobility must be assumed in this area already in the 57th century calBC, at the latest, and which developed fully independently of the "old" maritime networks of the Aegean. Only the Vardar zone and Pelagonia, via the plain of the Aliakmon, were influenced by the primary neolithisation in the 62 nd century calBC. The point of departure therefore seems to have been the SMA vegetation zone, which in this case encompasses the entire river valley. By contrast, the neolithisation of the zone of the Macedonian lakes of Prespa and Ohrid further west evidently occurred only later, in the first centuries of the 6th millennium calBC. But again, like in the Struma valley, the initial impulse towards neolithisation started off from the Aegean maritime networks and is clearly distinguishable from the terrestrial routes, above all in the Vardar zone (Fig. 4). Important substantiation of this process, aside from pottery comparisons, is provided by the architectural contexts in Anza II and Tumba Mađari as well as the plenteous use of Spondylus from the Aegean to make ornaments.

Regarding the question of agency in the Neolithisation of the Vardar zone and Pelagonia, the same obstacles arise as already encountered in the neighbouring Struma valley, to the East. It is difficult to imagine that the first herds of sheep, goats and cattle could have reached inland without guidance by shepherds, and this includes their movement as exchange goods. The appearance of a comprehensive Neolithic package constituted by cultivated plants, domesticated animals, advanced pottery production, and house construction is explainable only through the immigration of a population that was practicing an already fully Neolithic economy. Although this population must have arrived by the Mediterranean Sea, the relatively short period of time during which the Neolithic further disseminated via the land route, including the expansion from one fertile (but initially forested) flood-plain to the next through narrow river valleys and mountainous terrain, is indeed noteworthy. There are no traces in Macedonia of any Mesolithic settlement. Whether such settlements existed or not, and in our view the second assumption is the most likely, they played no part, or at least not any archaeologically discernible part, in the primary spread of the Neolithic in this area.

\subsection{Examination of the expansion hypothesis}

Finally, let us now re-examine the expansion hypothesis in the light of the results put forward above, which indicate that the geographical position of the earliest Neolithic settlements shows strong relations to certain bioclimatic properties of the present natural environment. To gain more insight into the bioclimatic regulation of archaeological site locations, we have used GIS software to extract the environmental characteristics of these sites based on available European geospatial data, i.e. the highresolution SRTM digital elevation model (Jarvis et al., 2008), ESDB soil data (Panos, 2006) and EuroVegMap vegetation maps (Bohn et al., 2003). The investigated parameters include elevation above sea level, aspect of the slope, soil texture and drainage, proximity to major rivers, potential natural vegetation, and several climatic variables. The results indicate that the majority of sites is located on well-drained soils with fine to medium textures, and situated within walking distance of rivers. In quantitative terms, more than $50 \%$ of the sites are situated closer than $6 \mathrm{~km}$ to the nearest major river, with an exception maximum distance of ca. $20 \mathrm{~km}$ for the site of Krajnici. The sites have low to moderate elevations, mainly below $300 \mathrm{~m}$, with a maximum elevation of $617 \mathrm{~m}$ asl for Krajnici. With respect to the slope aspect, sites do not show any preferential orientation. The natural vegetation, finally, is dominated by oak forests and alluvial forests. Most of the Early Neolithic sites belong to ecotones (i.e. transitional biomes) between lowlands and mountains (150-500 m asl), or wetlands and open oak forests (0-150 $\mathrm{m}$ asl), which are particularly rich in various natural resources and are situated in the wider zone of the thermophilous, mixed deciduous, broad-leaved forests (Fig. 5). In fact, both the completely developed Starčevo-Criş-Körös-Karanovo I-II, as well as Anzabegovo-Vršnik and the early Impresso complexes are all restricted to the SMA zone. Nevertheless, although this biogeoclimatic zonation provides a general framework for the later expansion of the Neolithic, it does not explain the absence of the earliest sites in Thrace and other regions of the Balkan Peninsula. In the following and last section of our paper we address this question in more detail.

\subsection{Mediterranean versus continental climate}

One main result of the GIS-studies, described above, was to identify the strong regionality that underlies the spread of farming in SE-Europe, in particular in its very earliest phases. The approach is now extended with the aim of correlating the archaeological data (mainly: settlement distributions, pottery-stylistic mapping) with the environmental and climatic data, first in terms of modern analogies for the hypothetical palaeo-vegetation, and then by comparison with the environmental conditions that were actually prevailing in SE-Europe during the Early Neolithic, based on a compilation of terrestrial and marine palaeoclimatic records. Concerning the southern parts of SE-Europe, the present situation is that droughts are more important factors than frost, whereas moving to the north, frost (especially in early spring) plays a much more decisive role. The reconstruction of the temperatures during the period following 6050 calBC shows that in SE-Europe the winter temperatures were typically almost at present-day values and summers were slightly cooler (Davis et al., 2003: 1711). Therefore, as goes for the periods following the earliest Neolithic, the climatic conditions in SE-Europe appear to have been more or less comparable with today. However, this does not apply to the previous period ( 6550-6050 calBC), for which there exists a wealth of strong evidence for the regular occurrence of polar air outbreaks during late winter or early spring, both in modern times (Saaroni et al., 1996) as well as in prehistoric periods (Marino et al., 2009; Pross et al., 2009; Rohling et al., 2002). We will come back to the meteorological discussion of corresponding RCC winter/spring conditions below, and for the moment put further focus on the palaeobotanical aspects of SE-European winter and summer conditions.

Olives, representing a modern crop but which can be used as sensitive indicator also of the Mediterranean palaeo-climate, do not endure the harsh northern Greek and Bulgarian winters, and from a comparative regional perspective this is due to the existence of a strong climatic and vegetational gradient that separates these regions from the milder Aegean coastal regions. Naturally, therefore, both the crops and associated methods of food-processing introduced from the Mediterranean and Near East into these northern regions of the Balkans would have had to be adapted to such coldwinter conditions, hence, we now perceive these adaptations as representing an important agricultural transition that must have occurred somewhere between the eastern Mediterranean and the Balkans during the very earliest phase of the Early Neolithic. The most suitable corridor for such an environmental adaptation to take place smoothly is the area of the northwestern Aegean 


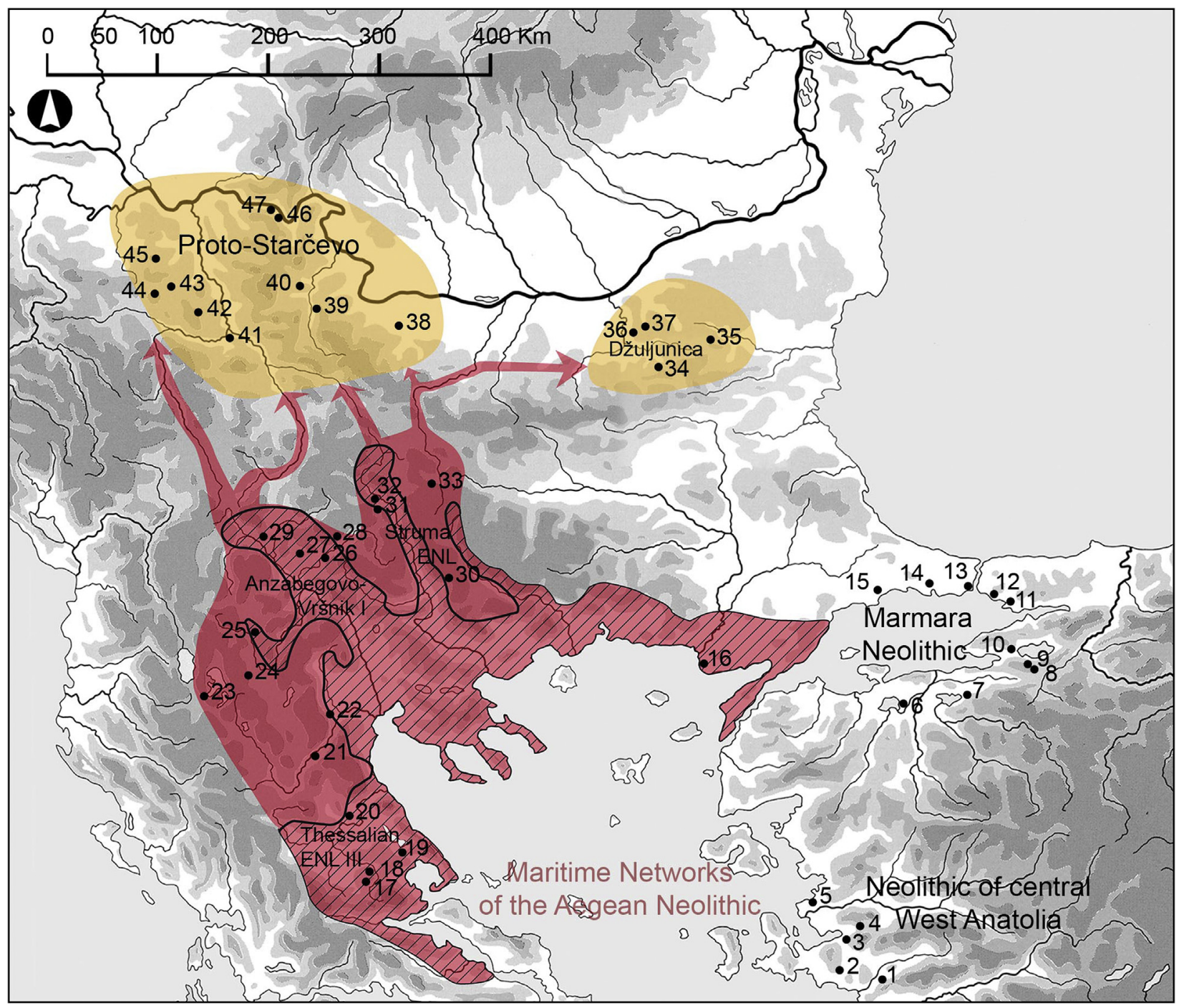

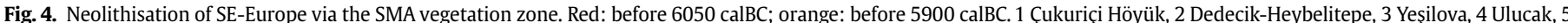

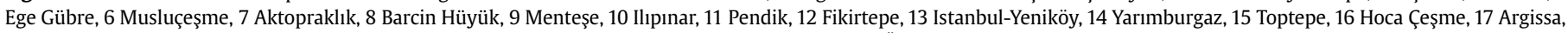

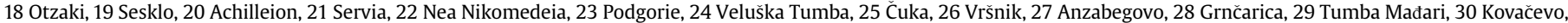

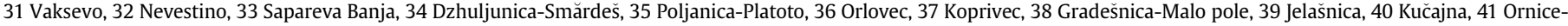
Makrešani, 42 Blagotin, 43 Divostin, 44 Grivac, 45 Banja Aranđelovac, 46 Lepenski Vir, 47 Padina

(Thessaly) and further, in the lower river valleys of Vardar, Struma and Mesta.

Looking at the modern vegetation in this region, we see it is dominated by Albanian-Macedonian-Greek, mixed Oriental hornbeam-downy oak forests, that are clearly of subMediterranean character and which are indeed representative for mild winters (Fig. 6 and Table 1). But now looking further to the East, beyond the fertile plains of northern Greece, the question arises as to why the earliest Early Neolithic - when moving North did apparently not pass through Thrace? Instead, as it appears from data assembled in Table 1, the expansion to the North only took place along the north-south oriented river systems of the Central Balkans. Again, a comparison of the modern vegetation in both regions provides us with an important key to addressing this question. Today, the Thracian Oriental hornbeam-downy oak forests are well-adapted to the prevailing strongly continental influence with regular winter frosts and an average temperature of the coldest month ca. $2-3{ }^{\circ} \mathrm{C}$ lower than in the Sub-Mediterranean regions of the Central Balkans. Indeed, the first Neolithic groups appeared in regions that have, amongst others, a higher average temperature of the coldest month, approximately similar to that in the Mediterranean. Such conditions are most likely to be present in the Sub-Mediterranean biogeographic region. Once established (for bioclimatic reasons) in such regions, the further expansion to the North would naturally have followed the north-south oriented river systems of the Central Balkans.

In support of these qualitative model expectations, finally, we have organised the data such that it is capable of making further, quantitative predictions. To this purpose, we have used the same environmental and climatic parameters as introduced above. Using the method of Single Linkage Cluster Analysis (SLCA) which is integrated in the PAST-statistics package (Hammer et al., 2001), we obtained the results shown in Fig. 7. SLCA is a nearest-neighbour type of analysis in which the clusters are shown in a dendrogram for which the similarities and distinct splitting levels are defined according to the smallest distances between the paired elements. The distance matrix is computed by using Pearson's correlation coefficient as similarity measure, whereby the sample values and 


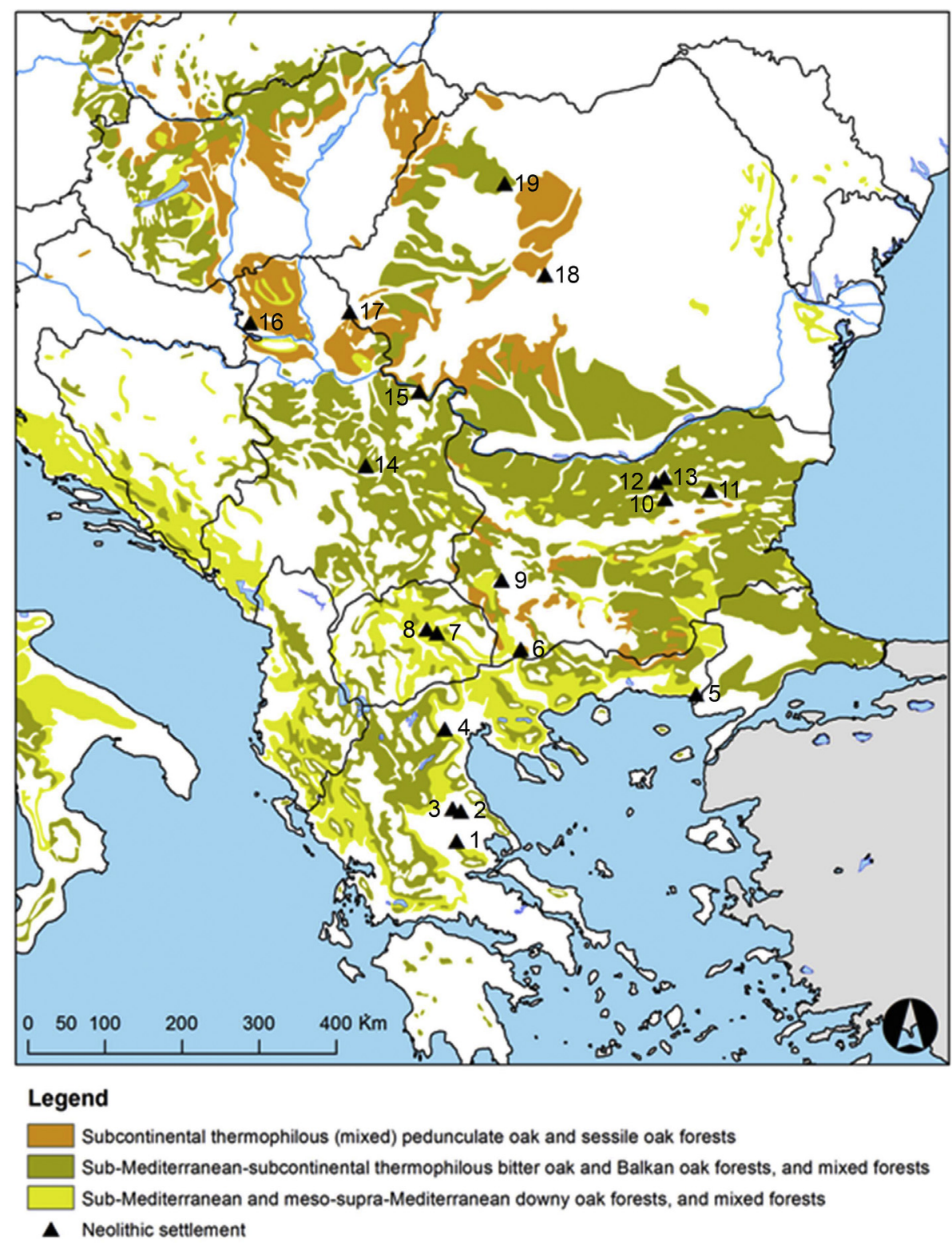

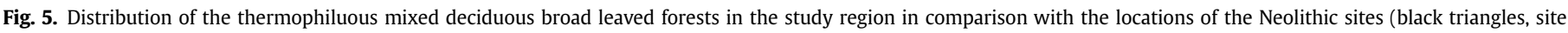
reference see Fig. 7) considered. Extract of the Map of the Natural Vegetation of Europe, Scale 1:2,500,000 (Bohn et al., 2003 ).

their standard deviations are first centred by subtracting the mean, and then scaled by dividing by the standard deviation. An advantage of the method is that it can be used with non-normalized data and can trace the trend in the matrix. The most important result of this study, in our view, is to demonstrate the existence of four clearly separated clusters of archaeological sites. Put differently, each site-cluster is now uniquely distinguished (only) in terms of the associated environmental and climatic parameters. The first cluster contains the Thessalian sites (Achilleion, Argissa, Otzaki). The next brings together the Macedonian site of Nea Nikomedeia with Hoca Çeşme (situated at the mouth of Marica River). The sites of Anzabegovo and Vršnik in the Vardar river valley falls in one cluster with the sites of Kovačevo and Krajnici (both situated in the Struma river valley). These first three clusters are clearly distinct from the fourth major cluster, that is formed by the Early Neolithic sites in northern Bulgaria (Dzhuljunica, Koprivec, Orlovec and Poljanica-Platoto), but which also contains sites in the Central Balkans (Lepenski Vir, Blagotin), along with Foeni-Salaş and Donja
Branjevina, i.e. sites located in the flat regions of the southern Carpathian Basin, and, finally, the two Transylvanian sites Ocna Sibiului and Gura Baciului. Due to a general lack of high-resolution ${ }^{14} \mathrm{C}$-site chronologies in southern Europe, and notably also in Thessaly, at the present state-of-research it is impossible to reliably interprete the chronological background of the first three siteclusters. What is presently only clear is that the fourth major cluster (with sites from N-Bulgaria, the Central Balkans, and the Carpathian Basin) apparently covers Neolithic sites (we should better state: settlement environments) that were (exclusively) established later than $\sim 6100$ calBC i.e. following the end of the Hudson-Bay-outflow (Weninger et al., 2009).

\subsection{The position of Thrace within the rapid climate corridor}

These results fit well with a variety of chronological observations, both in terms of pottery similarities as well as ${ }^{14} \mathrm{C}$-ages. For example, in Thessaly, the earliest (known) Early Neolithic 


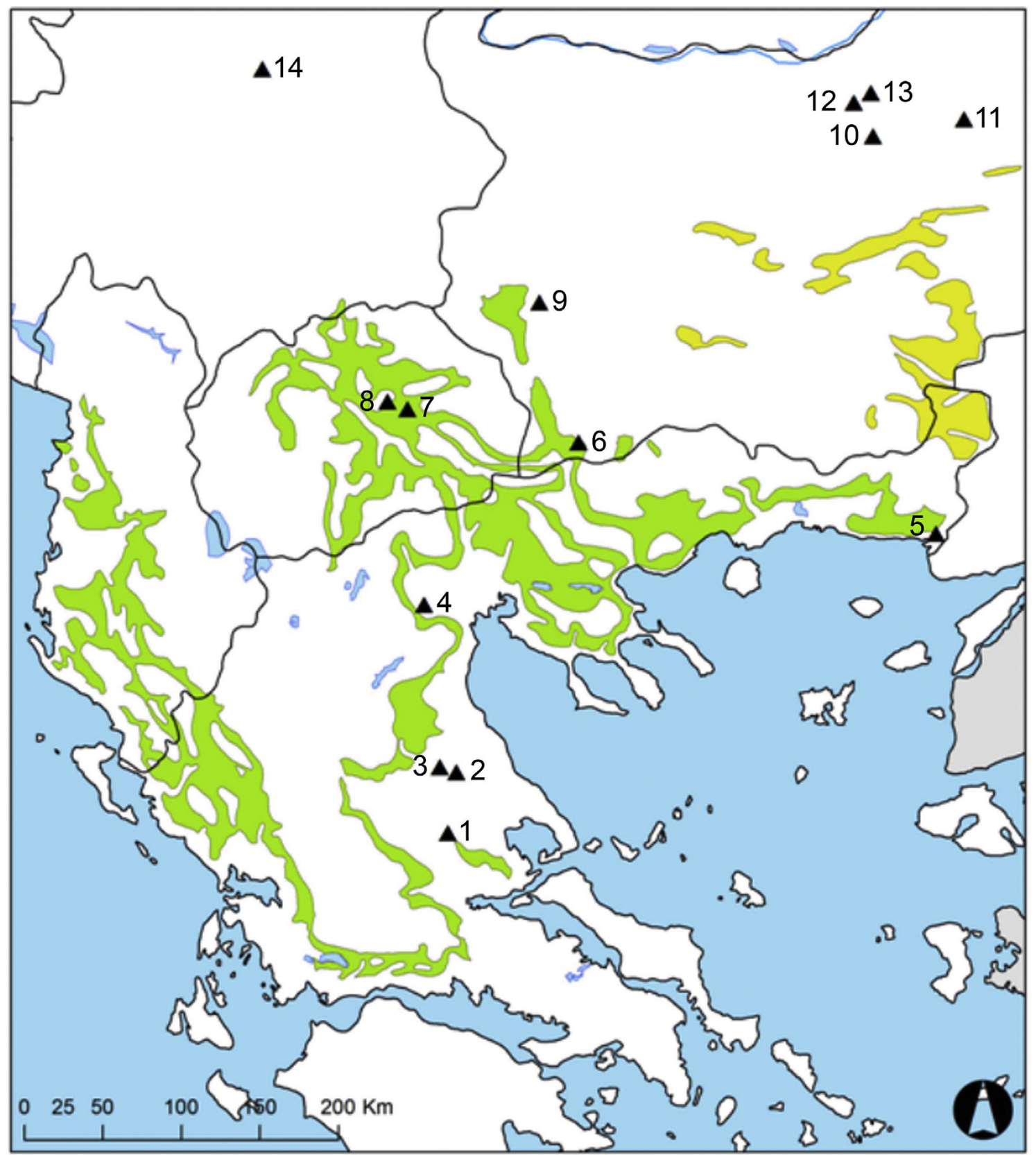

\section{Legend}

\section{Thracian Oriental hombeam-downy oak forests \\ Albanian-Macedonian-Greek mixed Oriental hornbeam-downy oak forests}

\section{$\Delta$ Neolithic settlement}

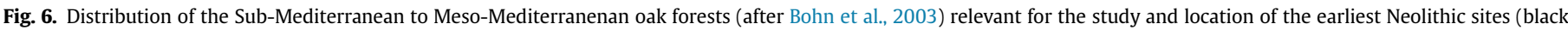
triangles, site reference see Fig. 7).

settlement appears to begins after 6400 calBC (Reingruber, 2008: 316f.) and the pottery has an age similar to that of Hacilar in Anatolia (Brami and Heyd, 2011). Unfortunately, discussion of comparative stratigraphy sensu strictu (i.e. the combination of architectural stratigraphies, pottery synchronisms, ${ }^{14} \mathrm{C}$-ages, and cultural relations) is strongly complicated by the almost complete lack of ${ }^{14} \mathrm{C}$-ages on stratified, short-lived samples in all our study regions (Thessaly, Greece, Anatolia). Nevertheless, in combination, recent archaeological studies based on pottery synchronisms between Anatolian and Greek sites (e.g. Çilingiroglu, 2010; Brami and Heyd, 2011; Reingruber, 2011), and recent new ${ }^{14} \mathrm{C}$-ages for the northern Greek sites of Mavropygi (Karamitroi-Mentessidi et al.,

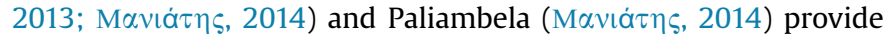
further insights into the cultural developments within the Aegean, inside the long RCC-interval.

What can be stated already now, at higher dating resolution 
Table 1

Main climatic and environmental constrains for the vegetation types shown on Fig. 4.

\begin{tabular}{|c|c|c|}
\hline & Albanian-Macedonian & Thracian \\
\hline Average annual temperature: & $12-13^{\circ} \mathrm{C}$ & $10-12{ }^{\circ} \mathrm{C}$ \\
\hline Average annual precipitation: & $550-600 \mathrm{~mm}$ & $590-600 \mathrm{~mm}$ \\
\hline Average temperature of the warmest month: & July $23-25{ }^{\circ} \mathrm{C}$ & July $20-22{ }^{\circ} \mathrm{C}$ \\
\hline Average temperature of the coldest month: & January $1-2{ }^{\circ} \mathrm{C}$ & January -2 to $0{ }^{\circ} \mathrm{C}$ \\
\hline Local climate or other climatic peculiarities: & $\begin{array}{l}\text { Warm, summer-dry climate, in the north } \\
\text { continentally influenced }\end{array}$ & $\begin{array}{l}\text { Subcontinental-Sub-Mediterranean transition, } \\
\text { climate with frosts in the winter }\end{array}$ \\
\hline
\end{tabular}

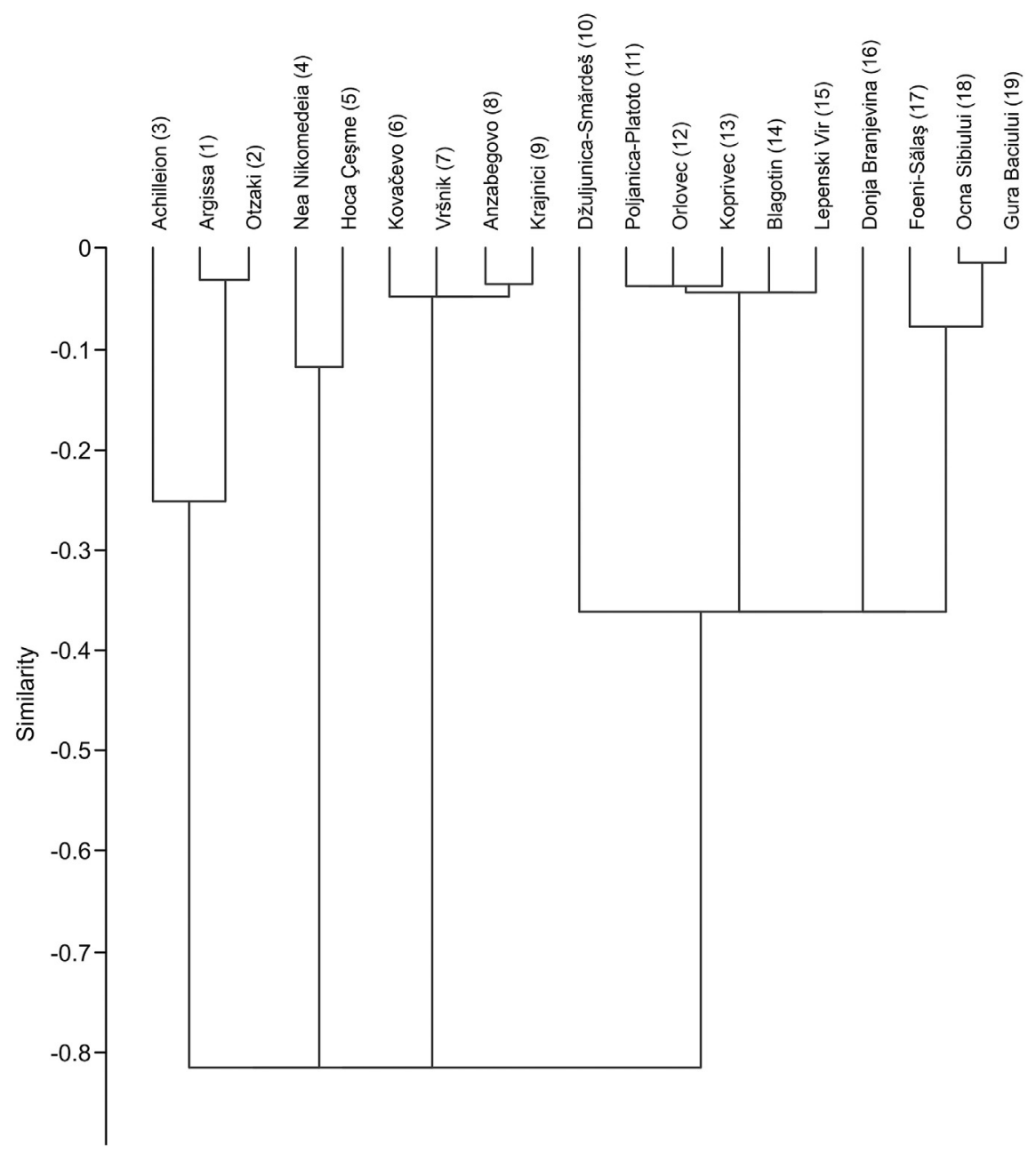

Fig. 7. Results of the SLCA applied on the environmental parameters of the considered Neolithic sites. Environmental parameters given on Table 2.

(decadel scale), is that there exist some quite remarkable synchronisms between the earliest arrival of the Neolithic at a number of large sites on the west coast of Turkey (Çukuriçi Höyük, Ulucak, and only slightly later at Barcin) and its earliest arrival on the Peloponnese (Franchthi Cave) at around 6550 calBC.

This arrival is synchronous (within error limits of $\sim 100 \mathrm{yrs}$ ) with the onset of RCC-conditions in the Eastern Mediterranean. On the other hand, the departure from the Aegean, and in particular the further dispersal of the Neolithic in northern direction through the Central Balkans into the Pannonian Basin only occurs after 6050 calBC i.e. immediately (1-3 generations) following the end of RCC conditions (Weninger et al., 2014).

Notwithstanding remaining problems of 'climate determinism', that for some of our colleagues are still under discussion (e.g. Berger et al., 2016), in our view it is now only a small remaining step to connect the observed geographic distribution of Early Neolithic sites within the Sub-Mediterranean-Aegean Vegetation Zone, both with the observed 500 year delay in Neolithic dissemination, and with the extreme climatic conditions that are known to be prevailing during the $8.6-8.0$ ka calBP interval of Rapid Climate Change (RRC). As illustrated in the RCC climate records (Figs. 8-9), from the climatological perspective, the very existence of the SMA Vegetation Zone is related to its geographic position simultaneously in close proximity to the warm Aegean, as well as within the geographic corridor for influx of cold air masses from the polar regions into the Aegean during RCC-times (Weninger and Harper, 2015). Of archaeological interest, the RCC-winds have their main occurrence during late winter and early spring, at which times we may expect the farming communities to have highest cold-climatic vulnerability. Geographically, the RCC-corridor for polar air begins 
Table 2

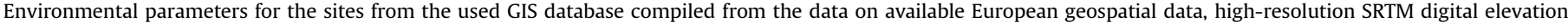
models (Jarvis et al., 2008), ESDB soil data (Panos, 2006) and European vegetation maps (Bohn et al., 2003).

\begin{tabular}{|c|c|c|c|c|c|c|c|c|}
\hline & $\begin{array}{l}\text { EuroVegMap } \\
\text { vegetation }\end{array}$ & $\begin{array}{l}\text { SRTM } \\
\text { aspect } \\
\text { class }\end{array}$ & $\begin{array}{l}\text { SRTM } \\
\text { elevation } \\
\text { ( } \mathrm{m} \text { a.s.l.) }\end{array}$ & $\begin{array}{l}\text { Distance } \\
\text { to major } \\
\text { rivers }(\mathrm{m})\end{array}$ & $\begin{array}{l}\text { ESDB soil } \\
\text { texture }\end{array}$ & $\begin{array}{l}\text { ESDB soil } \\
\text { drainage }\end{array}$ & $\begin{array}{l}\text { Average temperature } \\
\text { of the coldest month }\end{array}$ & Climate \\
\hline Achilleion & G57 & SE-SW & 286 & 5672 & Medium & dry & 1 to $2{ }^{\circ} \mathrm{C}$ & $\begin{array}{l}\text { Warm, summer-dry climate, in } \\
\text { the north continantally } \\
\text { influenced }\end{array}$ \\
\hline Argissa & U35 & NE-SE & 70 & 5080 & Fine & dry & 4 to $9{ }^{\circ} \mathrm{C}$ & $\begin{array}{l}\text { long-term summer droughts in } \\
\text { the east Balkan; areas with } \\
\text { continentally tinged } \\
\text { Mediterranean climate }\end{array}$ \\
\hline Otzaki & U38 & NE-SE & 78 & 1208 & Fine & dry & $7-12{ }^{\circ} \mathrm{C}$ & $\begin{array}{l}\text { warm, Mediterranean with } \\
\text { mild winters and long dry } \\
\text { seasons in summer }\end{array}$ \\
\hline Nea Nikomedeia & U18 & NE-SE & 7 & 1063 & Medium & dry & 0 to $2{ }^{\circ} \mathrm{C}$ & $\begin{array}{l}\text { mild, moderately continental } \\
\text { tinged, summer-warm climate }\end{array}$ \\
\hline Hoca Çeşme & U36 & SE-SW & 10 & 2193 & Very fine & dry & 0 to $1{ }^{\circ} \mathrm{C}$ & $\begin{array}{l}\text { summer-warm, continentally } \\
\text { tinged climate }\end{array}$ \\
\hline Kovačevo & G57 & SE-SW & 493 & 15,138 & Fine & dry & 1 to $2{ }^{\circ} \mathrm{C}$ & $\begin{array}{l}\text { Warm, summer-dry climate, in } \\
\text { the north continantally } \\
\text { influenced }\end{array}$ \\
\hline Vršnik & G57 & SW-NW & 282 & 4684 & Coarse & No Data & 1 to $2{ }^{\circ} \mathrm{C}$ & $\begin{array}{l}\text { Warm, summer-dry climate, in } \\
\text { the north continantally } \\
\text { influenced }\end{array}$ \\
\hline Anzabegovo & U35 & NW-NE & 323 & 8846 & Medium & No Data & 4 to $9{ }^{\circ} \mathrm{C}$ & $\begin{array}{l}\text { long-term summer droughts in } \\
\text { the east Balkan; areas with } \\
\text { continentally tinged } \\
\text { Mediterranean climate }\end{array}$ \\
\hline Krajnici & U18 & SW-NW & 617 & 20,142 & Fine & dry & 0 to $2{ }^{\circ} \mathrm{C}$ & $\begin{array}{l}\text { mild, moderately continental } \\
\text { tinged, summer-warm climate }\end{array}$ \\
\hline Dzhuljunica & F67 & NW-NE & 66 & 1063 & Medium fine & dry & -1 to $2{ }^{\circ} \mathrm{C}$ & $\begin{array}{l}\text { Warm, moderately continental } \\
\text { climate }\end{array}$ \\
\hline Poljanica-Platoto & F67 & NE-SE & 241 & 15,501 & Medium fine & dry & -1 to $2{ }^{\circ} \mathrm{C}$ & $\begin{array}{l}\text { Warm, moderately continental } \\
\text { climate }\end{array}$ \\
\hline Orlovec & F68 & NE-SE & 305 & 5800 & Medium fine & dry & -1 to 3 & $\begin{array}{l}\text { Warm, moderately continental } \\
\text { climate }\end{array}$ \\
\hline Koprivec & G22 & SE-SW & 176 & 13,829 & Medium fine & dry & 0 to $3{ }^{\circ} \mathrm{C}$ & $\begin{array}{l}\text { Moderately continental and } \\
\text { continental-sub-Mediterranean } \\
\text { transition climate }\end{array}$ \\
\hline Blagotin & G19 & SW-NW & 259 & 9415 & No Data & No Data & -2 to $0{ }^{\circ} \mathrm{C}$ & warm, dry summers \\
\hline Lepenski Vir & G8 & SE-SW & 391 & 2594 & Coarse & No Data & -2 to $-1{ }^{\circ} \mathrm{C}$ & $\begin{array}{l}\text { warm and dry microclimate on } \\
\text { sunexposed slopes in the south }\end{array}$ \\
\hline Donja Branjevina & $\mathrm{F} 47$ & NW-NE & 79 & 13,789 & Medium fine & No Data & 0 to $-2{ }^{\circ} \mathrm{C}$ & \\
\hline Foeni-Salaş & P32 & SE-SW & 76 & 5964 & Medium fine & dry & -7 to $-3{ }^{\circ} \mathrm{C}$ & $\begin{array}{l}\text { warm and dry; annual climatic } \\
\text { water deficiencies on more } \\
\text { than } 150 \text { days; high frequency } \\
\text { of winds and strength }\end{array}$ \\
\hline Ocna Sibiului & G3 & SW-NW & 535 & 13,652 & Medium & dry & -5 to $-4{ }^{\circ} \mathrm{C}$ & $\begin{array}{l}\text { opposing local climatic } \\
\text { conditions from cool to } \\
\text { moderately dry on northern } \\
\text { slopes to hot to dry on steep } \\
\text { south exposed slopes }\end{array}$ \\
\hline Gura Baciului & G16 & NW-NE & 429 & 19,431 & Medium & $\begin{array}{l}\text { humid to } \\
\text { very humid }\end{array}$ & -4 to $-1{ }^{\circ} \mathrm{C}$ & $\begin{array}{l}\text { In late summer an enduring } \\
\text { drought of several weeks is } \\
\text { possible }\end{array}$ \\
\hline
\end{tabular}

in regions north of the Himalaya, runs through the North Pontic steppe regions, crosses the Lower Danube, and runs from there into northern Greece. Following orographic channeling through the Balkans, the cold winds then proceed southwards across the Aegean Sea (cf. Weninger et al., 2014). In combination with results put forward above, we may now expect the geographically complex orographic channeling of cold air masses through the Balkans to contribute to the observed large micro-climatic vegetational variability. Major changes both in terrestrial and marine ecosystems during the 8.6-8.0 ka calBP RCC-interval period are already now documented in a large number of archives and this motivates further studies as to the micro-regional vegetational impact of RCC. Our present studies may provide guidance for such studies, in that Thrace appears to be the region most strongly affected by RCC. This is presently indicated by the archaeological data, and follows also from recognition that Thrace is one of the main terrestrial regions for entry of RCC winds into the north-east Aegean. This hypothesis is further indicated by the unusually high frequency and severity of polar outbreaks that are known to occur in the north-eastern corner of the Mediterranean basin (Saaroni et al., 1996). Altogether, it can hardly be a 'chance' coincidence that the Neolithic disseminated both into and out of the Aegean exactly in phase (within given error limits) with begin and end of RCC-conditions. Already by ca. 5900 calBC, Neolithic settlement can be confirmed in all landscapes of the Balkans, as far North as the southern Carpathian Basin, and even in Thrace for the first time.

\section{Conclusions}

In the present paper we introduce a possible explanation for 


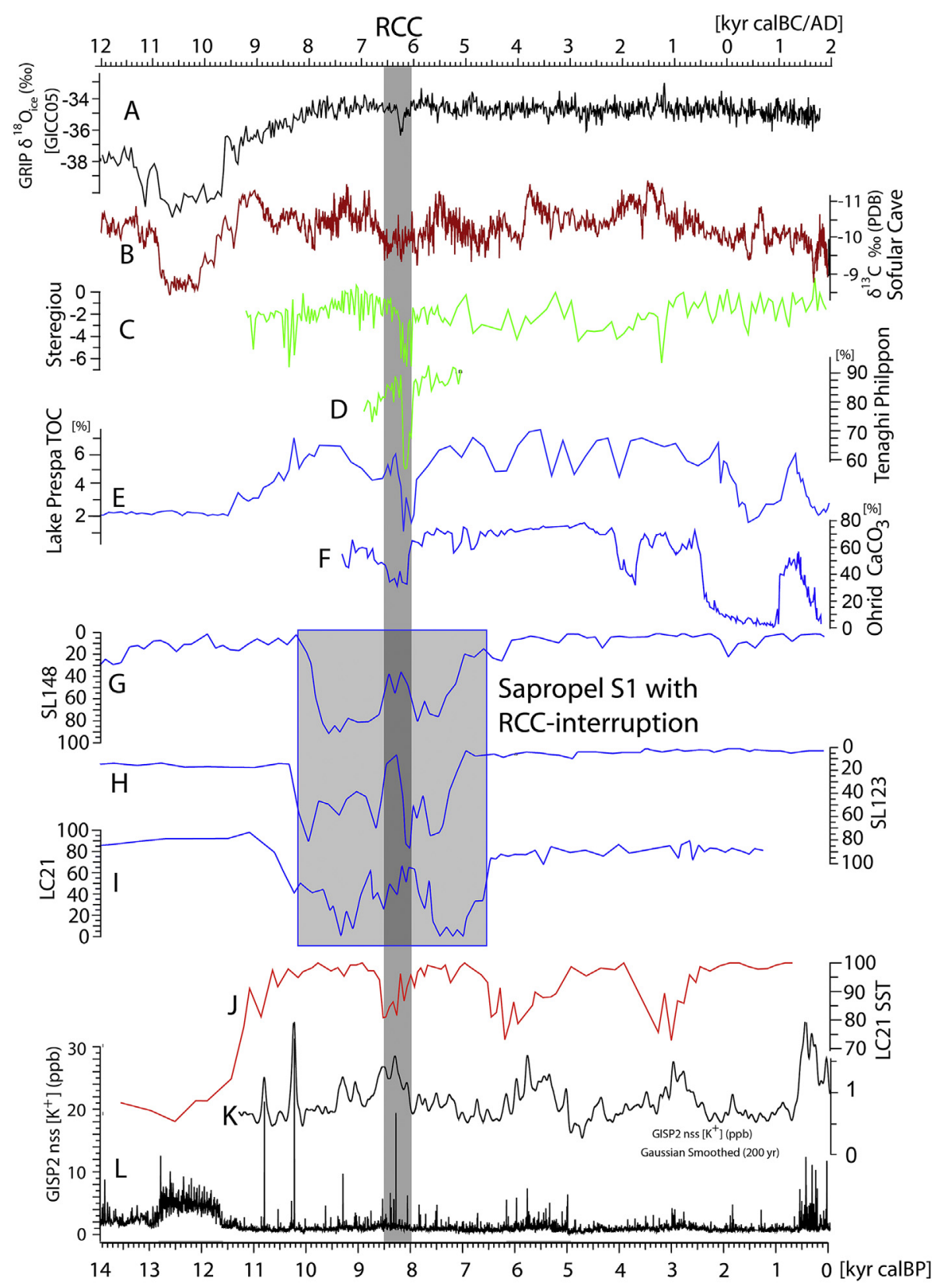

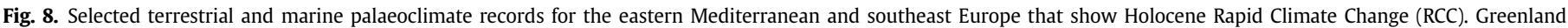

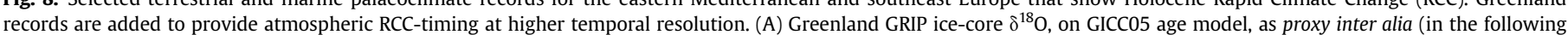

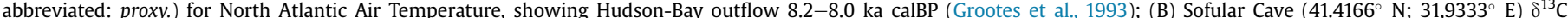

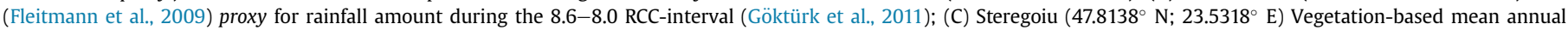

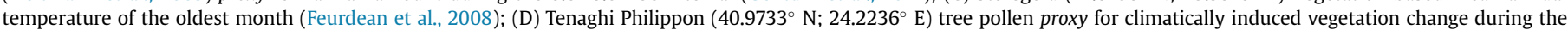

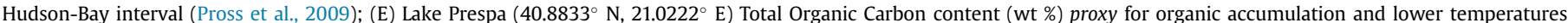

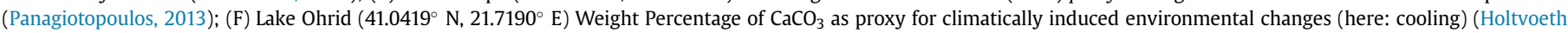

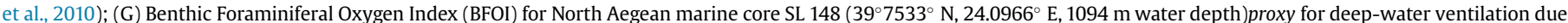

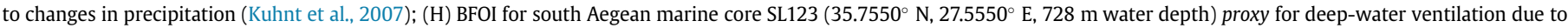

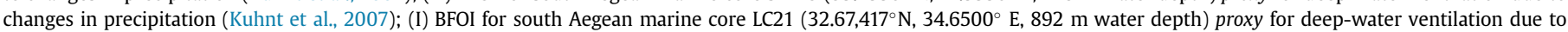

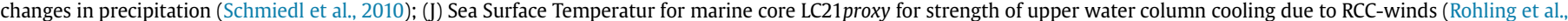

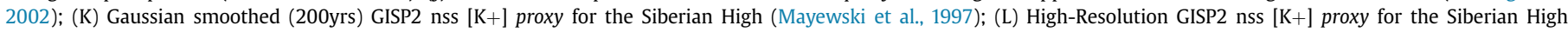
(Mayewski et al., 1997).

certain geographic preferences that are apparent in the pathways used by Neolithic communities during their initial colonization of the Aegean and southern Europe. Our studies are based on GIS analysis of environmental factors related to site distribution, and on palaeo-climatological observations aside with modern analogies, both in combination with a wide variety of archaeological observations. Starting point is the observation that the farmers/ herders initially avoid the foundation of settlements in Thrace. Although to some extent speculative due to missing data (and in particular in lack of high-resolution ${ }^{14} \mathrm{C}$-ages for the majority of study sites), our approach is nevertheless aimed at achieving a deeper understanding of the processes underlying the spread of 


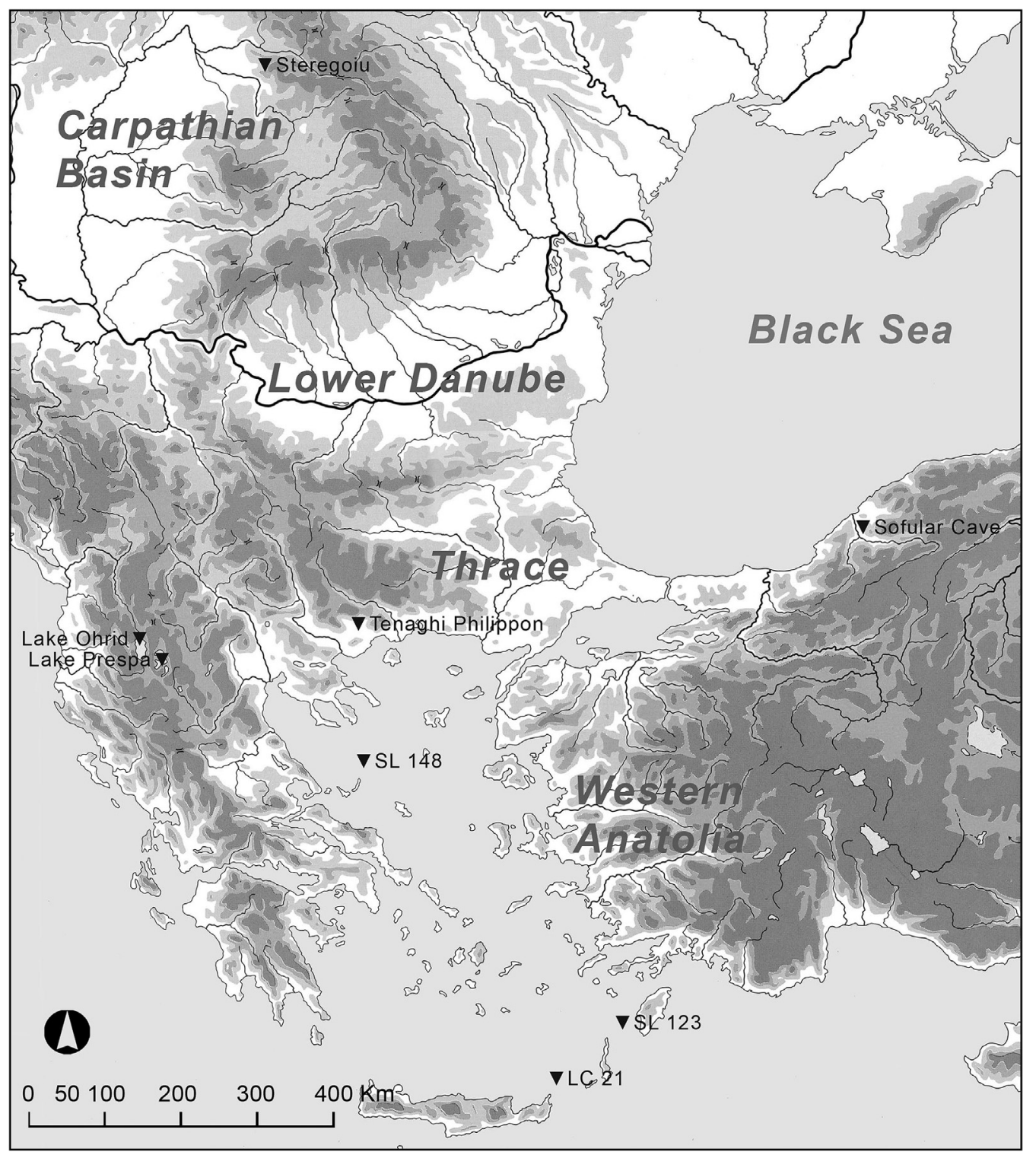

Fig. 9. Map showing location of paleoclimate records in Fig. 8.

the oldest Early Neolithic out of the circum-Aegean regions into the Balkans. The modelling is based upon comparisons of the modern natural environments in the southern Balkans and the Aegean with the (assumed) corresponding prehistoric settlement patterns. With this approach, a number of close similarities between regional microclimates and archaeological patterns become apparent, and in particular the vegetational patterns provide an explanation for the observed absence of oldest Early Neolithic settlements in Thrace. As can be observed in modern times, the Thracian Oriental hornbeam-downy oak forests are exposed to a much stronger continental influence than those measured for SMA vegetation in the Central Balkans, with extensive frosts in the winter and average temperatures of the coldest month that are ca. $2-3{ }^{\circ} \mathrm{C}$ lower. The existence of such milder Sub-Mediterranean conditions in parts of the Balkans, although not widely acknowledged, could be one of the main reasons why the first Neolithic groups initially appeared in these very specific regions, which would have had all-year-round conditions quite similar to those even on the Mediterranean coasts. Assuming that such conditions, as can be observed today in the Balkans (far-inland in the SMA biogeographic region), also existed at the time of the 6550-6050 calBC RCC-event, then we can simultaneously explain both the long ( 500 year) delay of the Neolithic in the circum-Aegean regions, as well as the extremely rapid ( $\max 200 \mathrm{yrs}$ ) and longdistance $(\sim 2000 \mathrm{~km})$ further dissemination of early farming, immediately following the end of the RCC-interval. This further Neolithic expansion to the North followed the north-south oriented river systems of the Central Balkans. In order to live in regions beyond the Aegean with an economy based on agriculture and stockbreeding solely, the Neolithic package first had to be adapted to conditions of the relatively harsh winters in the Balkans. Only following this period of climatic and environmental adaptation, it was possible to apply the Neolithic lifestyle to the neighbouring areas, such as Thrace, Walachia, Dobrudzha and the Carpathian Basin.

\section{References}

Alram-Stern, E., 1996. Die Ägäische Frühzeit. 2. Serie, Bd. 1, Das Neolithikum in Griechenland mit Ausnahme von Kreta und Zypern (Wien 1996). 
Ammermann, A., Cavalli-Sforza, L.L., 1984. The Neolithic and the Genetics of Populations in Europe (Princeton 1984).

Andreou, S., Fotiadis, M., Kotsakis, K., 2001. The neolithic and bronze age of northern Greece. In Aegean Prehistory: a Review. In: Cullen, T. (Ed.), American Journal of Archaeology, Supplement vol. 1. Archaeological Institute of America, Boston, pp. 259-327.

Aurenche, O., Kozłowski, S.K., 1999. La naissance du Néolithique au Proche Orient ou le paradis perdu (Paris 1999).

Bajnóczi, B., Schöll-Barna, G. Kalicz, N., Siklósi, Zs, Hourmouziadis, G.H., Ifantidis, F. Kyparissi-Apostolika, A., Pappa, M., 2013. Tracing the source of Late Neolithic Spondylus shell ornaments by stable isotope geochemistry and cathodoluminescence microscopy. J. Archaeol. Sci. 40, 874-882.

Bar-Yosef, O., 2011. Climatic fluctuations and early farming in west and east asia. Curr. Anthropol. 52 (S4), S175-S193.

Benz, M., 2000. Die Neolithisierung im Vorderen Orient. Theorien, archäologische Daten und ein ethnologisches Modell (Berlin 2000).

Berger, J.-F., Lespez, L., Kuzucuoglu, C., Glais, A., Hourani, F., Barra, A., Guilaine, J., 2016. Interactions between climate change and human activities during the early to mid-Holocene in the eastern Mediterranean basins. Clim. Past. 12 1847-1877.

Bergner, M., Horejs, B., Pernicka, R., 2009. Zur Herkunft der Obsidianartefakte von Çukuriçi Höyük. Stud. Troica, Band. 18, 249-271.

Beuermann, A., 1967. Fernweidewirtschaft in Südosteuropa. Ein Beitrag zur Kulturgeographie des östlichen Mittelmeergebietes. Westermann, München 1967.

Bohn, U., Gollub, G., Hettwer, C., Neuhäuslová, Z., Raus, T., Schlüter, H., Weber, H. 2003. Karte der natürlichen Vegetation Europas/map of the natural vegetation of Europe. Maßstab/Scale 1 : 2500 000. Landwirtschaftsverlag, Münster.

Bollongino, R., Elsner, J., Vigne, J.-D., Burger, J., 2008. Y-SNPs do not indicate hybridisation between european aurochs and domestic cattle. PLoS One 3 (10), e3418.

Bollongino, R., Burger, J., Powell, A., Mashkour, M., Vigne, J.-D., Thomas, M.G., 2015. Modern taurine cattle descended from small number of near-eastern founders. Mol. Biol. Evol. 29 (9), 2101-2104.

Braidwood, R.J., 1952. The Near East and the Foundations for Civilization: an Essay in Appraisal of the General Evidence (Oregon 1952).

Brami, M., Heyd, V., 2011. The origins of Europe's first farmers: the role of Hacilar and Western Anatolia, fifty years on. Praehistorische Z. 86/2 (2011), 165-206.

Cikovac, P., 2002. Soziologie und standortbedingte Verbreitung tannenreicher Wälder im Orjen Gebirge (Montenegro) (München 2002).

Çilingiroglu, Ç., 2010. The appearance of impressed pottery in the neolithic aegean and its implications for maritime networks. TÜBA-AR 13, 9-22.

Clare, L., 2010. Pastoral clashes: conflict risk and migration at the pottery neolithic transition in the southern levant. Neo-Lithics 1 (2010), 13-31.

Clare, L., 2016. Culture Change and Continuity in the Eastern Mediterranean during Rapid Climate Change: Assessing Impacts of a Little Ice Age in the 7th Millennium CalBC. Kölner Studien zur Prähistorischen Archäologie 7. VML Verlag Marie Leidorf GmbH, Bonn.

Clare, L. Weninger, B., 2014. The dispersal of neolithic lifeways: absolute chronology and rapid climate change in central and west Anatolia. In: Özdoğan, M. Başgelen, N., Kuniholm (Hrsg), P. (Eds.), The Neolithic in Turkey, vol. 6, pp. 1-65. Istanbul 2014.

Davis, B., Brewe, S., Stevenson, A., Guiot, J., 2003. Data Contributors. The temperature of Europe during the Holocene reconstructed from pollen data. Quat. Sci. Rev. 22, 1701-1716.

Feurdean, A., Klotz, S., Mosbrugger, V., Wohlfarth, B., 2008. Pollen-based quantitative reconstructions of Holocene climate variability in NW Romania. Palaeoclimatol. Palaeogeogr. Palaeoecol. 260, 494-504.

Fleitmann, D., Cheng, H., Badertscher, S., Edwards, R.L., Mudelsee, M., Göktürk, O.M., Fankhauser, A., Pickering, R., Raible, C.C., Matter, A., Kramers, J., Tüysüz, O., 2009. Timing and climatic impact of Greenland interstadials recorded in stalagmites from northern Turkey. Geophys. Res. Lett. 36, L19707. http://dx.doi.org/ 10.1029/2009GL040050.

Geörg, Ch, 2013. Paläopopulationsgenetik von Schwein und Schaf in Südosteuropa und Transkaukasien. Menschen - Kulturen - Traditionen. Studien aus den Forschungsclustern des Deutschen Archäologischen Instituts 4 (Rahden 2013).

Gerritsen, F., Ozbal, R., Thissen, L., 2013. Barcin Höyük. The beginnings of farming in the Marmara region. In: Özdoğan, M., Başgelen, N., Kuniholm (Hrsg), P. (Eds.) The Neolithic in Turkey, vol. 5, pp. 93-112. Istanbul 2013.

Ghilardi, M., Fouache, E. Queyrel, F. Syrides, G., Vouvalidis, K., Kunesch, S., Styllas, M., Stiros, S., 2008. Human occupation and geomorphological evolution of the Thessaloniki Plain (Greece) since mid Holocene. J. Archaeol. Sci. 35, $111-125$

Gimbutas, M., Winn, Sh, Shimabuku, D., 1989. Achilleion. A Neolithic Settlement in Thessaly, Greece, 6400-5600 BC (Los Angeles 1989).

Gimbutas, M. (Ed.), 1976. Neolithic Macedonia as reflected by Excavation at Anza, Southeast Yugoslavia (Los Angeles).

Göktürk, O.M., Fleitmann, D., Badertscher, S., Cheng, H., Edwards, R.L. Leuenberger, M., Fankhauser, A., Tüysüz, O., Kramers, J., 2011. Climate on the southern black sea coast during the Holocene: implications from the sofular Cave record. Quat. Sci. Rev. 30, 2433-2445.

Grootes, P.M., Stuiver, M., White, J.W.C., Johnsen, S., Jouzel, J., 1993. Comparison o oxygen isotope records from the GISP2 and GRIP Greenland ice core. Nature $366,552-554$

Guilaine, J., 2000/2001. La diffusion de lagriculture en Europe: une hypothèse arythmique. Zephyrus 53/54, 267-272.
Halstead, P., Isaakidou, V., 2013. Early stock-keeping in Greece. In: Colledge, S., Conolly, J., Dobney, K., Manning, K., Shennan, S. (Eds.), The Origins and Spread of Domestic Animals in Southwest Asia and Europe, pp. 129-143.

Hammer, Ø., Harper, D.A.T., Ryan, P.D., 2001. Past: paleontological statistics software package for education and data analysis. Palaeontol. Electron. 4 (1), 9.

Hofmanová, Z., Kreutzer, S., Hellenthal, G., Sell, Ch, Diekmann, Y., Díez-delMolino, D., van Dorp, L., López, S., Kousathanas, A., Link, V., Kirsanow, K., Cassidy, L.M., Martiniano, R., Strobel, M., Scheu, A., Kotsakis, K., Halstead, P., Triantaphyllou, S., Kyparissi-Apostolika, N., Urem-Kotsou, D.-Ch, Ziota, Ch, Adaktylou, F., Gopalan, Sh, Bobo, D.M., Winkelbach, L., Blöcher, J., Unterländer, M., Leuenberger, Ch, Çilingiroğlu, Ç., Horejs, B., Gerritsen, F., Shennan, S., Bradley, D.G., Currat, M., Veeramah, K.R., Wegmann, D. Thomas, M.G., Papageorgopoulou, Ch, Burger, J., 2016. Early farmers from across europe directly descended from Neolithic Aegeans. PNAS 113 (25), 6886-6891. http://dx.doi.org/10.1073/pnas.1523951113.

Holtvoeth, J., Vogel, H., Wagner, B., Wolff, G.A., 2010. Lipid biomarkers in Holocene and glacial sediments from ancient Lake Ohrid (Macedonia, Albania). Biogeosciences 7, 3473-3489. http://dx.doi.org/10.5194/bg-7-3473-2010.

Horejs, B., Milić, B., Ostmann, F., Thanheiser, U., Weninger, B., Galik, A., 2015. The aegean in the early 7th millennium BC. Maritime networks and colonization. J. World Prehistory 28 (4), 289-330.

Jarvis, A., Reuter, H.I., Nelson, A., Guevara, E., 2008. Hole-filled SRTM for the globe Version 4. Available from the CGIAR-CSI SRTM 90m http://srtm.csi.cgiar.org.

Kanzurova, E., Zdravkovski, D., 2011. Latest archaeological research regarding the neolithic period in the republic of Macedonia. In: Krauß, R. (Ed.), Beginnings New Research in the Appearance of the Neolithic between Northwest Anatolia and the Carpathian Basin. Menschen - Kulturen - Traditionen. Studien aus den Forschungsclustern des Deutschen Archäologischen Instituts 1 (Rahden 2011), pp. 139-155.

Karamitroi-Mentessidi, G., Efstratiou, N., Kozłowski, J.K., Kaczanowska, M., Maniatis, Y., Curci, A., Michalopoulou, S., Papathanasiou, A., Valamoti, S.M., 2013. New evidence on the beginning of farming in Greece: the Early Neolithic settlement of Mavropigi in western Macedonia (Greece). Antiquity 087 (335) (zizertaoleRar, reecMew).

Karul, N., Avcı, M., 2013. Aktopraklık,. In: Özdoğan, M., Başgelen, N., Kuniholm, P. (Eds.), The Neolithic in Turkey, vol. 5, pp. 45-68. Istanbul 2013.

Krahtopoulou A. and Veropoulidou R. Late Pleistocene-Holocene shoreline reconstruction and human exploitation of molluscan resources in northern Pieria, Macedonia, GreeceJ. Archaeol. Sci.2016(in press), http://dx.doi.org/10.1016/j. jasrep.2016.02.003

Krauß, R. 2011. On the 'monochrome' neolithic in southeast Europe. In: Krauß (Hrsg), R. (Ed.), Beginnings - New Research in the Appearance of the Neolithic between Northwest Anatolia and the Carpathian Basin. Menschen - Kulturen Traditionen. Studien aus den Forschungsclustern des Deutschen Archäologischen Instituts 1 (Rahden 2011), pp. 109-125.

Krauß, R., 2016. Zur Symbolik des Rindes im europäischen Neolithikum. In: Băchvarov, K., Gleser, R. (Eds.), Southeast Europe and Anatolia in Prehistory: Essays in Honor of Vassil Nikolov on His 65th Anniversary, vol. 293. Universitätsforschungen zur Prähistorischen Archäologie, pp. 233-251. Bonn 2016.

Krauß, R., 2017. Nordwestanatolien, Balkan und Karpatenbecken im diachronen Vergleich - kulturkontakt und Kommunikation vom 6.-4. Jt.v.Chr. In: Schimmelpfennig, D., Link, T. (Eds.), Fokus Jungsteinzeit - Berichte der AG Neolithikum 5 in press; Kerpen-Loogh.

Krauß, R., Elenski, N., Weninger, B., Clare, L., Çakırlar, C., Zidarov, P., 2014. Beginnings of the neolithic in southeast Europe. The early neolithic sequence and absolute dates from Džuljunica-smărdeš (Bulgaria). Doc. Praehist. XLI, 51-77.

Kuhnt, T., Schmiedl, G., Ehrmann, W., Hamann, Y., Hemleben, C., 2007. Deep-sea ecosystem variability of the aegean sea during the past $22 \mathrm{kyr}$ as revealed by benthic foraminifera. Mar. Micropaleontol. 64, 141-162.

Lespez, L., Dalongeville, R., Noirel-Schutz, C., Suc, J.-P., Koukouli-Chryssanthaki, H., Treuil, R., 2000. Les paléoenvironnements du site préhistorique de Dikili Tash (Macédoine orientale, Grèce). 2. In: Bulletin de correspondance hellénique, 124, pp. 413-434 livraison.

Lespez, L., Tsirtsoni, Z., Darcque, P., Koukouli-Chryssanthraki, H., Malamidou, D., Treuil, R. and Oberlin, C., 2013. The lowest levels at Dikili tash, northern Greece: a missing link in the Early Neolithic of Europe. Antiquity 87: 30-45.

Lichardus-Itten, M., Demoule, J.-P., Perničeva, L., Grebska-Kulova, M., Kulov, I., 2002. The site of Kovačevo and the beginning of the neolithic period in southwestern Bulgaria. In: Lichardus-Itten, M., Lichardus, J., Nikolov, V. (Eds.), Beiträge zu jungsteinzeitlichen Forschungen in Bulgarien. Saarbrücker Beiträge zur Altertumskunde, 74, pp. 99-158. Bonn 2002.

Lichardus-Itten, M., Demoule, J.-P., Pernicheva, L., Grebska-Kulova, M., Kulov, I., 2006. Kovačevo, an early neolithic site in south-west Bulgaria and its importance for european neolithization. In: Gatsov, I., Schwarzberg, H. (Eds.), Aegean - Marmara - Black Sea: the Present State of Research on the Early Neolithic. Schriften des Zentrums für Archäologie und Kulturgeschichte des Schwarzmeerraumes, vol. 5, pp. 83-94. Langenweissbach 2006.

Lichter, C., 2011. Neolithic stamps and the neolithization process. A fresh look at an old issue. In: Krauß, R. (Ed.), Beginnings - New Research in the Appearance of the Neolithic between Northwest Anatolia and the Carpathian Basin. Menschen - Kulturen - Traditionen. Studien aus den Forschungsclustern des Deutschen Archäologischen Instituts 1 (Rahden 2011), pp. 35-44.

Malinowski, B., 1922. [1979]. Argonauts of the Western Pacific. Routledge and Kegan Paul Ltd. German Edition: Argonauten des westlichen Pazifik. Ein Bericht über Unternehmungen und Abenteuer der Eingeborenen in den Inselwelten von 
Melanesisch-Neuguinea. Syndikat, Frankfurt am Main 1979.

Marino, G., Rohling, E.J., Sangiorgi, F., Hayes, A., Casford, J.L., Lotter, A.F., Kucera, M. Brinkhuis, H., 2009. Early and middle Holocene in the aegean sea: interplay between high and low latitude climate variability. Quat. Sci. Rev. 28 (27-28), 3246-3262.

Marinova, E., 2006. Vergleichende paläeoethnobotanische Untersuchung zur Vegetationsgeschichte und prähistorischen Landnutzung in Bulgarien. Dissertationes Botanicae. J. Cramer in Gebr. Borntraeger Verlagsbuchhandlung. Science Publishers (Stuttgart) nr.401.

Matsanova, V., 1996. Cult objects from the early neolithic site at the town of Rakitovo. Poročilo o raziskovanju paleolitika, neolitika eneolitika v Sloveniji 23, 105-127.

Mayewski, P.A., Meeker, L.D., Twickler, M.S., Whitlow, S., Yang, Q., Lyons, W.B., Prentice, M., 1997. Major features and forcing of high- latitude northern hemisphere atmospheric circulation using a 110,000- year long glaciochemical series. J. Geophys. Res. 102, 26345-26366.

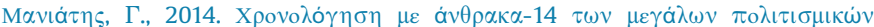

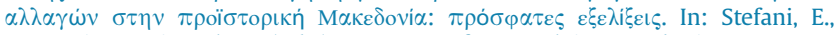
Merousis, N., Dimoula, A. (Eds.), A Century of Research in Macedonia 1912-2012. International Conference Proceedings, Archaeological Museum of Thessaloniki, 22-24 November 2012: 205-222.

Milić, M., 2014. PXRF characterisation of obsidian from central Anatolia, the Aegean and central Europe. J. Archaeol. Sci. 41, 285-296.

Milojčić, V., 1983. Otzaki-magula II. Das Mittlere Neolithikum. Die mittelneolithische Siedlung, Bonn.

Nikolov, V., 1990. Das Flusstal der Struma an der frühneolithischen Strasse von Anatolien nach Mitteleuropa. In: Die Ersten Bauern. Ausstellungskatalog (Zürich 1990), pp. 63-69.

Özdoğan, M., 2011. An anatolian perspective on the neolithization process in the Balkans. New questions, new prospects. In: Krauß, R. (Ed.), Beginnings - New Research in the Appearance of the Neolithic between Northwest Anatolia and the Carpathian Basin. Menschen - Kulturen - Traditionen. Studien aus den Forschungsclustern des Deutschen Archäologischen Instituts 1 (Rahden 2011), pp. 23-33.

Özdogan, M., 2014. A new look at the introduction of the Neolithic way of life in Southeastern Europe. Changing paradigms of the expansion of the Neolithic way of life. Doc. Praehist. 41 (2014), 33-49.

Panagiotopoulos, K., 2013. Late Quaternary Ecosystem and Climate Interactions in SW Balkans Inferred from Lake Prespa Sediments. Diss. Köln. Available under. http://kups.ub.uni-koeln.de/5518/.

Panos, P., The European soil database (2006) GEO: connexion, 5 (7), pp. 32-33: The European Soil Database distribution version 2.0, European Commission and the European Soil Bureau Network, CD-ROM, EUR 19945 EN, 2004

Perlès, C., 2001. The Early Neolithic in Greece: The First Farming Communities in Europe (Cambridge 2001).

Pernicheva-Perets, L., Grębska-Kulow, M., Kolov, I., 2011. Balgarchevo. Prehist. Settl. I (Sofia 2011).

Pross, J., Kotthoff, U., Müller, U.C., Peyron, O., Dormoy, I., Schmiedl, G., Kalaitzidis, S., Smith, A.M., 2009. Massive perturbation in terrestrial ecosystems of the eastern mediterranean region associated with the 8.2 kyr BP climatic event. Geology 37 (10), 887-890.

Reingruber, A., 2008. Die Argissa-Magula II. Das frühe und das beginnende mittlere Neolithikum im Lichte transägäischer Beziehungen (Bonn 2008).

Reingruber, A., 2011. Early Neolithic settlement patterns and exchange networks in the Aegean. Doc. Praehist. XXXVIII, 291-305.

Riehl, S., Asouti, E., Karakaya, D., Starkovich, B.M., Zeidi, M., Conard, N.J., 2015.
Resilience at the transition to agriculture: the long-term landscape and resource development at the aceramic neolithic tell site of chogha golan (Iran). BioMed Res. Int. 2015, 22.

Rohling, E.J., Mayewski, P., Abu-Zied, R., Casford, J., Hayes, A., 2002. Holocene atmosphere-ocean interactions: records from Greenland and the aegean sea. Clim. Dyn. 18 (7), 587-593.

Roodenberg, J., Alpaslan-Roodenberg, S., 2013. Ilıpınar and Menteşe. Early farming communities in the eastern Marmara. In: Özdoğan, M., Başgelen, N., Kuniholn (Hrsg), P. (Eds.), The Neolithic in Turkey, vol. 5, pp. 69-91. Istanbul 2013.

Saaroni, H., Bitan, A., Alpert, P., Ziv, B., 1996. Continental polar outbreaks into the levant and eastern Mediterranean. Int. J. Climatol. 16, 1175-1191.

Scheu, A., 2012. Palaeogenetische Studien zur Populationsgeschichte von Rind und Ziege mit einem Schwerpunkt auf dem Neolithikum in Südosteuropa. Menschen - Kulturen - Traditionen. Studien aus den Forschungsclustern des Deutschen Archäologischen Instituts 4 (Rahden 2012).

Scheu, A., Powell, A., Bollongino, R., Vigne, J-D., Tresset, A., Cakırlar, C., Benecke, N. Burger, J., 2015. The genetic prehistory of domesticated cattle from their origin to the spread across Europe. BMC Genet. 16, 54.

Schmiedl, G., Kuhnt, T., Ehrmann, W., Emeis, K.-C., Hamann, Y., Kotthoff, U. Dulski, P., Pross, J., 2010. Climatic forcing of eastern mediteranean ecosystems during the past 22000 years. Quat. Sci. Rev. 29, 3006-3020.

Srejović, D., 1973. Lepenski Vir. Eine vorgeschichtliche Geburtsstätte europäischer Kultur. Erweiterte Ausgabe mit einem revidierten und erweiterten Originalbeitrag von Hans Quitta (Bergisch Gladbach 1973).

Theocharis, D., 1973. Neolithic Greece (Athens 1973).

Todorova, H., 1990. Das Frühneolithikum Nordbulgariens im Kontext des ostbalkanischen Neolithikums. In: Die Ersten Bauern. Ausstellungskatalog (Zürich 1990), pp. 71-76.

Urem-Kotsou, D., Papaioannou, A., Papadakou, T., Saridaki, N., Intze, Z., 2014. Pottery and stylistic boundaries. Early and middle neolithic pottery in Macedonia. In Stefani, E., Merousis, N., Dimoula, A. (Eds.), A Century of Research in Prehistoric Macedonia 1912-2012 (Thessaloniki 2014), pp. 505-517.

Watkins, T., 2007. Der Naturraum in Anatolien. Ein Zusammenspiel von Klima, Umwelt und Ressourcen. In: Siebenmorgen, H. (Ed), Vor 12.000 Jahren in Anatolien. Die ältesten Monumente der Menschheit. Ausstellungskatalog Karlsruhe (Stuttgart 2007), pp. 37-47.

Weninger, B., Harper, T., 2015. The geographic corridor for rapid climate change in southeast Europe and Ukraine. In: Schultze, E. (Ed.), Neolithic and Copper Age between the Carpathians and the Aegean, 31. Archäologie in Eurasien, DAI Berlin, pp. 475-505.

Weninger, B., Clare, L., Rohling, E., Bar-Yosef, O., Böhner, U., Budja, M. Bundschuh, M., Feurdean, A., Gebel, H.G., Jöris, O., Linstädter, J., Mayewski, P., Mühlenbruch, T., Reingruber, A., Rollefson, G., Schyle, D., Thissen, L. Todorova, H., Zielhofer, Ch, 2009. The impact of rapid climate change on prehistoric societies during the holocene in the eastern mediterranean. Doc. Praehist. 36, 7-59.

Weninger, B., Clare, L., Gerritsen, F., Horejs, B., Krauß, R., Linstädter, J., Ozbal, R. Rohling, E.J., 2014. Neolithisation of the aegean and southeast Europe during the 6600-6000 calBC period of rapid climate change. Doc. Praehist. 41, 1-31.

Zeder, M.A., 2008. Domestication and early agriculture in the mediterranean basin origins, diffusion, and impact. PNAS 105 (33), 11597-11604.

Zohary, D., Hopf, M., Weiss, E., 2012. Domestication of Plants in the Old World, fourth ed. Oxford University Press, Oxford.

Zvelebil, M., 2001. The agricultural transition and the origins of Neolithic society in Europe. Doc. Praehist. 28, 1-26. 